Personality Approaches to Political Behavior

Dr. Bert N. Bakker

Associate Professor

Amsterdam School of Communication Research

University of Amsterdam

Personal: www . bertbakker.com

Lab: wwww.hotpolitics.eu

Twitter: @bnbakker

Chapter is part of the forthcoming Oxford Handbook of Political Psychology (2022) 


\title{
Personality Approaches to Political Behavior
}

\begin{abstract}
Whether personality is relevant for political behavior is a question that has a long tradition in political psychology. This chapter provides a comprehensive overview of the state-the-art evidence on the association between personality and political behavior of citizens and politicians. In particular, this chapter focuses on the association between personality and political ideology, voting behavior, political loyalties, political participation, political engagement, and news consumption. The chapter concludes by outlining a research agenda for the next generation of research with attention to the assumed causal effects of personality on political "outcomes". Future research is also encouraged to adopt open science practices that will increase transparency, replicability, and ultimately the field's credibility.

Key words: Personality, Ideology, Political Preferences, Political Behavior, Participation, Big Five, HEXACO, Authoritarianism, Dark Tetrad, Disgust sensitivity
\end{abstract}




\section{Introduction}

The question of whether personality is relevant for understanding political behavior has a long tradition in political psychology. ${ }^{1}$ Seminal studies in psychology and political science argued that a persons' psychological dispositions such as their "individual needs" (Adorno, Frenkel-Brenswik, Levinson, \& Sanford, 1950, p.2), "underlying needs" (Campbell, Converse, Miller, \& Donald, 1960, p.511) or "own inner feelings"

(McClosky, 1958, p.40) are important for political behavior. Over time slightly different theoretical approaches and specific personality traits have appeared. Nevertheless, the basic questions in the literature remained the same: can personality help us understand the variation in people's political preferences and behaviors.

Up to today, research on personality and politics contributes to fundamental research questions such as the nature of ideology (Feldman \& Johnston, 2014) and the origins of political participation (Dawkins, 2017; Weinschenk, Dawes, Kandler, Bell, \& Riemann, 2019). Moreover, political developments in the years before writing this chapter such as Brexit and the elections of Donald Trump and Bolsenaro - lead academics (Choma \& Hanoch, 2017; Dunn, 2015; Ludeke, Klitgaard, \& Vitriol, 2018) and pundits (Vox, 2016 New York Times, 2018) to turn to personality as - part of - the answer for these political developments.

This chapter provides the historical context and discusses state-the-art theories on the role of personality in political behavior. At the same time, I outline a research agenda with essential questions and methodological innovations for the next generation of research.

This chapter is structured as follows. First, prominent models of personality will be discussed. Next, some shared features of the research designs in the personality-politics literature will be discussed. This is followed by a discussion about the associations between personality and various aspects of political behavior: political ideology, voting behavior, the strength of political loyalties, participation, engagement, and news consumption. A separate section reviews the relationship between the personality of politicians and their political behavior. The chapter ends with a discussion of open-ended questions and the call to adopt open science practices.

\section{What is personality?}

Allport (1937, p. 48) defined personality as the study of the "dynamic organization within the individual of those psychological systems that determine his unique adjustments to the environment." This chapter follows Mondak (2010, p. 6) who defined personality as "a multifaceted and enduring internal, or psychological, structure" usually consisting of multiple traits. Traits are "broad internal dimensions .... that account for consistencies in behavior, thought, and feeling across situations and time" (McAdams \& Olson, 2010, p. 519).

There are various models of personality and different theories (see for discussions, Eysenck \& Eysenck, 1968; Feher \& Vernon, 2021; Goldberg, 1990). It goes beyond the scope of this chapter to discuss all of them. Here the Big Five personality traits,

\footnotetext{
${ }^{1}$ The author wants to thank editor Jennifer Jerit for the extensive feedback on this chapter. Conversations with Vin Arceneaux, John Bullock, Robert Klemmensen, Yphtach Lelkes, Ariel Malka, Alessandro Nai, Matthijs Rooduijn, Gijs Schumacher, and Claes de Vreese inspired many of the points raised in this chapter.
} 
HEXACO model, Dark Tetrad, and the traits Authoritarianism and Disgust Sensitivity will be discussed.

\section{The Big Five personality traits}

The Big Five model of personality is a prominent model in the personality-politics literature. The lexical hypothesis underlying the Big Five suggests "that natural languages such as English would have evolved terms for all fundamental individual differences" (McCrae \& Costa, 1985, p. 711). In a series of pioneering studies, Allport and colleagues (Allport, 1937; Allport \& Odbert, 1936) isolated thousands personality-descriptive terms from an English language dictionary, categorized these terms and created a list of terms they considered to be stable traits. Factor analyses suggested that personality is best represented using a five-factor structure (Digman, 1990; Fiske, 1949; Goldberg, 1992; Tupes \& Christal, 1992). These traits were coined the "Big Five" and labelled: Extraversion, Agreeableness, Conscientiousness, Neuroticism, and Intellect (Digman, 1990; Goldberg, 1992).

Inspired by the research in the lexical tradition, Costa Jr and McCrae (1992) developed the Five-Factor Model with the traits Openness, Conscientiousness, Extraversion, Agreeableness, and Neuroticism. ${ }^{2}$ The Five-Factor Model differed a bit from the "Big Five": the model relied upon short sentences instead of single-word person-adjectives to measure personality, the content of the Openness (vs. Intellect in the Big Five) trait differed, and the traits consisted of lower-order facets. Both models have been used in the literature, and throughout the chapter the term Big Five will be used. ${ }^{3}$

The Big Five integrates a wide variety of individual differences into five traits. Key characteristics of the five traits are:

- Openness: Openness encapsulates variation in the sensitivity for art, beauty, and feelings. It also captures variation in the willingness to try new activities, the tendency to consider new ideas and to re-evaluate one's social and political beliefs (McCrae, 1996).

- Conscientiousness: Conscientiousness captures the tendency to resist impulses and plan, organize and carry out tasks (Costa Jr, McCrae, \& Dye, 1991). Conscientiousness has a pro-active and an inhibitive side. As Costa Jr et al. (1991, p. 889) explain "the proactive side of Conscientiousness is seen most clearly in the need for achievement and commitment to work". "The inhibitive side" of Conscientiousness "is seen in moral scrupulousness and cautiousness' (Costa Jr et al., 1991, p. 889)".

- Extraversion: Extraversion is associated with the experience of positive emotions, a tendency to be outgoing and prefer action, as well as excitement seeking. Highly extraverted individuals are outgoing, socially engaged; seek excitement; like to be in the center of attention, and experience positive emotions. Those lower on Extraversion are shy and prefer to stay in the background.

\footnotetext{
2 Costa and McCrae (1995, p. 23) use the word "domain" where the word "trait" is used here.

${ }^{3}$ In the chapter, Openness instead of Intellect will be used as this seems to be the more common labeling for the trait in the personality-politics literature.
} 
- Agreeableness: Agreeableness "is primarily a dimension of interpersonal behavior" (Costa Jr et al., 1991, p.889). Yet, Agreeableness "also influences the self-image and helps to shape social attitudes and philosophy of life" (Costa Jr et al., 1991, p.889). Those higher on Agreeableness are trusting, caring, believe in the good intentions of others, avoid conflict, and are tender-minded (Costa Jr et al., 1991). Those lower on Agreeableness are distrusting, cynical, tough-minded, and conflict-seeking.

- Neuroticism: Neuroticism is a trait that captures variation in the tendency to experience negative affect, anger, anxiety and depression. Moreover, Neuroticism captures variation in the extent to which people are self-conscious and insecure.

The Big Five's characteristics received widespread scholarly attention. The traits show high rank-order stability over time (Roberts \& DelVecchio, 2000). There is also a considerable degree of correspondence between self-ratings and observer-ratings of the Big Five (Costa \& McCrae, 1988). The Big Five structure has been replicated in samples representative of populations in different countries across cultures (Schmitt, Allik, McCrae, \& Benet-Martínez, 2007) - but see Laajaj et al. (2019). The Big Five traits have a sizeable heritable component (Vukasović \& Bratko, 2015) and manifest themselves in childhood (Edmonds, Goldberg, Hampson, \& Barckley, 2013). Finally, the Big Five traits reliably correlate with a wide variety of attitudes and behaviors (Soto, 2019).

\section{HEXACO model}

The HEXACO model of personality is, just like the Big Five, derived upon lexical studies across different languages (Lee \& Ashton, 2008). However, the HEXACO model suggests that personality consists of six broad traits (or domains) (Ashton \& Lee, 2007). There is considerable overlap between the HEXACO traits and those in the Big Five. The traits Openness to Experience, Conscientiousness, and Extraversion in the HEXACO are similar to those in the Big Five. The HEXACO trait Emotionality is related to Neuroticism but "excludes the anger that defines" those high Neuroticism in the Big Five (Ashton \& Lee, 2007, p. 152). Moreover, the HEXACO trait Emotionality "includes the sentimentality that mainly defines Big Five Agreeableness" (Ashton \& Lee, 2007, p. 152). Agreeableness is a trait that "is somewhat reminiscent of Big Five Agreeableness but excludes sentimentality and includes (lack of) anger" which is part of Neuroticism in the Big Five (Ashton \& Lee, 2007, p. 152). Honest-Humility is the, unique, sixth dimension of the HEXACO model (Ashton, Lee, \& De Vries, 2014). Honest-Humility captures variation in "sincerity, unassumingness, and fairness versus slyness/deceit, pretentiousness, and greed" (Ashton et al., 2006, p. 853). Like the Big Five traits, the psychometric properties, such as internal consistency, test-retest reliability, and convergent validity - of the HEXACO are acceptable (see, De Vries, 2013; Lee \& Ashton, 2006)

\section{Dark Tetrad}

The Dark Tetrad - an updated version of the Dark Triad (Paulhus \& Williams, 2002) - consists of the traits Narcissism, Machiavellianism, Psychopathy, and Sadism (Buckels, Jones, \& Paulhus, 2013) and captures antisocial personality traits that are not well represented in the Big Five (Block, 2010). Those higher on Narcissism seek power 
and attention, are self-absorbed, and entitled (Emmons, 1984). Machiavellianism is the trait that captures variation in the tendency to be self-interested and deceive and manipulate others (Jakobwitz \& Egan, 2006). High levels of Psychopathy are associated with higher levels of impulsiveness and thrill-seeking as well as lower levels of anxiety and empathy (Paulhus \& Williams, 2002). Finally, higher levels of everyday Sadism are associated with the degrading treatment of others, aggression, and cruelty (Buckels et al., 2013). The Dark Tetrad traits are positively correlated with each other and have acceptable psychometric properties (Buckels et al., 2013; Jonason \& Webster, 2010). The Dark Tetrad traits are to some extent correlated with the Big Five and HEXACO traits but these associations are modest (Fernández-del Río, Ramos-Villagrasa, \& Barrada, 2020; Paulhus \& Williams, 2002).

\section{Authoritarianism}

Authoritarianism has been a concept of interest for political psychologists dating back to work by Adorno et al. (1950). Authoritarianism is a personality trait "that values social cohesion and conformity to in-group norms over personal freedom and individual autonomy" (Engelhardt, Feldman, \& Hetherington, 2021, p. 4). Questions tapping into child-rearing values provide a valid and reliable measure of Authoritarianism (Feldman, 2003). Using this measure, Authoritarianism is stable over time and exogenous from politics (Engelhardt et al., 2021) and relatively independent from other personality traits such as the Big Five (Bakker, Rooduijn, \& Schumacher, 2016; Bakker, Schumacher, \& Rooduijn, 2021). ${ }^{4}$

\section{Disgust Sensitivity}

Disgust Sensitivity is an individual difference in the tendency to experience the emotion of disgust. As Fournier, Petersen, and Soroka (2021, p.1) explain "neurotypical individuals are all able to experience the feeling of disgust" but "research suggests that individuals differ in how easily the feeling is elicited." Tybur, Lieberman, and Griskevicius (2009) isolated three domains of individual differences in Disgust Sensitivity: individual variability in sensitivity to pathogens, sexual acts, and immoral behavior. Individual differences in Disgust Sensitivity are pretty stable across situations and over time (Sherlock, Zietsch, Tybur, \& Jern, 2016). Moreover, Disgust Sensitivity is relatively independent of the Big Five traits (Aarøe, Petersen, \& Arceneaux, 2017; Druschel \& Sherman, 1999).

\section{Common approaches to study the relationship between personality and politics}

This section contains a discussion of the design features of studies that are discussed in this chapter.

\section{Measurement of personality}

When measuring psychological traits, it is considered a best practice to rely upon more elaborate inventories (Cronbach, 1949). Commonly used measures of the Big Five range from 50 (Goldberg et al., 1999) to 240 items (Costa Jr \& McCrae, 2008) with

\footnotetext{
4 The F-scale and right-wing authoritarianism show substantial content overlap with political ideology (see for a detailed discussion Malka, Lelkes, \& Holzer, 2017) and will not be discussed in this chapter.
} 
excellent psychometric properties. However, the inclusion of 50 to 240 items is not always feasible. Longer surveys are costly and could lead to survey fatigue (Burisch, 1984). Finally, many researchers rely upon measures of personality included in omnibus surveys - like the American National Election Studies or British Election Studies - in which space is scarce and costly. As a consequence, many studies discussed in this chapter rely upon highly abbreviated measures of personality which capture personality with 1, 2, or 3 items per trait (see for overviews Bakker \& Lelkes, 2018; Bromme, Rothmund, \& Azevedo, 2022; Sibley, Osborne, \& Duckitt, 2012).

Brief measures of personality show acceptable test-retest reliability (Gerber, Huber, Doherty, \& Dowling, 2013; Gosling, Rentfrow, \& Swann Jr, 2003) and acceptable convergent validity - e.g., the degree to which a brief measure correlates with a longer measure of the same trait - (Donnellan, Oswald, Baird, \& Lucas, 2006; Rammstedt \& John, 2007). Brief measures, however, also have more problematic psychometric properties. Not surprising (Cronbach, 1949), brief measures are less reliable compared to longer measures (Bakker \& Lelkes, 2018; Gosling et al., 2003). But relying upon brief measures could also affect the conclusions researchers reach when it comes to the strength and the direction of the association with political behavior.

The use of brief measures could lead to a Type M (magnitude) error (Gelman \& Carlin, 2014) by wrongly concluding that a trait is not - or much weaker - associated with an outcome of interest (Bakker \& Lelkes, 2018; Credé, Harms, Niehorster, \& Gaye-Valentine, 2012). For example, Bakker (2018) show that the association between personality and ideology is weaker when relying on brief personality measures than more elaborate ones.

The possible Type-M error is not limited to brief measures of the Big Five. For example, an 8-item measure of authoritarianism leads to better predictive validity compared to the commonly used 4-item measure (Engelhardt et al., 2021). Likewise, a 1-item measure of Disgust Sensitivity leads to substantially weaker associations with political preferences compared to more extensive measures of disgust sensitivity (Fournier et al., 2021).

Throughout this chapter, the reader should remain cautious that null-findings in the personality-politics literature could result from the brief measures used in the literature discussed in this chapter.

The use of brief measures also increases the risk of a type S (sign) error (Gelman \& Carlin, 2014) when a brief personality measure taps into one sub-dimension of the trait. When the sub-dimension differentially correlates with the criterion measure compared to the broader trait, then the sign of the association might differ. Bakker and Lelkes (2018) do not find much evidence for a type-S error for the association between brief measures of personality and political ideology. Nevertheless, the risk of type $\mathrm{S}$ errors is there, and readers of the personality-politics literature should be mindful of this possibility, especially for bodies of research that only consist of a few studies and so far have resulted in conflicting findings.

\section{Study design}

The most common research design in the personality-politics literature is the cross-sectional design in which the personality inventory and the political outcome variables are measured in the same survey (see for recent overviews, Federico \& Malka, 2018; Johnston, Lavine, \& Federico, 2017). However, these studies by design cannot address the causal relationship between personality and politics. 
Panel studies that run over multiple years now include measures of personality. When personality is included at least once, it makes it possible to study whether personality is associated with change in certain political outcomes such as the change and stability in party preferences (Ekstrom \& Federico, 2019), vote choice (Bakker, Klemmensen, Nørgaard, \& Schumacher, 2016), party identification (Bakker, Hopmann, \& Persson, 2015) and political preferences (Bloeser, Canache, Mitchell, Mondak, \& Poore, 2015). Multiple measures of personality and politics among the same people open up the opportunity to study whether the relationship between personality and political outcomes is reciprocal (Bakker, Lelkes, \& Malka, 2021; Boston, Homola, Sinclair, Torres, \& Tucker, 2018; Hatemi \& Verhulst, 2015; Luttig, 2021).

Finally, personality traits are included in survey-experiments (Aarøe et al., 2017; Bakker, Schumacher, \& Rooduijn, 2021; Kalmoe, 2014; Kam \& Estes, 2016; Lyons, Sokhey, McClurg, \& Seib, 2016), field-experiments (Gerber, Huber, Doherty, Dowling, \& Panagopoulos, 2013), and laboratory experiments (Bakker, Schumacher, \& Homan, 2020) to serve as moderators of treatment effects.

\section{Samples}

The personality-politics literature relies upon convenience samples of students, online opt-in panels, and population-based studies. Results based upon convenience samples do not seem to differ from population-based studies (Clifford, Jewell, \& Waggoner, 2015; Vitriol, Larsen, Ludeke, \& Kandler, 2019). Yet, convenience samples are problematic if the variation in the dependent variable is limited (Druckman \& Kam, 2011). If a researcher is, for instance, interested in the association between personality and voting for populist parties, using a sample of college students could become problematic as it might be hard to find a lot of populist voters among college students.

Cross-cultural surveys that include personality and political preferences or behavior measures are rare. The World Values Survey (WVS), in its 6th wave, had a brief measure of the 10 item Big Five Inventory (Rammstedt \& John, 2007) in 25 countries. The WVS thereby provides a unique opportunity to study the association between personality and politics across various countries. Yet, the measure of personality in the WVS has problematic psychometric properties. Aside from being very brief - only two items per trait - Ludeke and Larsen (2017) showed there is a more fundamental psychometric problem with the measure of personality in the WVS. In the Netherlands and Germany - the two western Educated Industrialized Rich and Democratic (WEIRD) countries in the WVS - the inter-item correlations were positive and in line with earlier evidence. Yet in the non-WEIRD countries, Ludeke and Larsen (2017, p. 105) showed "there was typically no relationship between two items intended to assess a given trait". When "two items intended as the sole indicators of a trait do not correlate with each other, there is no reason to suppose that either item provides any meaningful information about that trait in that population" (Ludeke \& Larsen, 2017, p. 105).

Ludeke and Larsen (2017, p. 105) call to "carefully reconsider" the evidence-based upon this data. Studies that rely upon the WVS (e.g., Fatke, 2017) should thus be read with some degree of caution. The problems in the WVS should not discourage the study of personality across contexts, but careful assessment of the psychometric properties of the personality measures is needed. 


\section{Personality and survey responses}

Personality might condition the tendency to participate in surveys. In panel studies, unit non-response - e.g., not participating in one or more survey waves - is positively correlated with Openness and negatively with Conscientiousness (Cheng, Zamarro, \& Orriens, 2020). Using data from the American National Elections Studies, Valentino, Zhirkov, Hillygus, and Guay (2020) show that those higher on Openness have a lower probability of participating in an online survey, perhaps due to the individual and solitary nature of online surveys. However, Openness is also a robust correlate of ideology. As such, "Openness to Experience has both a direct effect on political preferences and an indirect one via differential propensities to participate in each mode" (Valentino et al., 2020, p. 457). These "results suggest that discrepancies in public opinion estimates driven by personality-related differences between fresh cross-sections and professionalized survey panels may be significant" (Valentino et al., 2020, p. 465).

Personality might also correlate with behavior in surveys. For example, item non-response - the tendency to report don't know or don't answer a question - is higher among people who are high in Neuroticism (Klingler, Hollibaugh, \& Ramey, 2018). A possible explanation for this finding is that those higher on Neuroticism are self-conscious and sensitive to making mistakes on questions that are difficult. Extreme response styles as well as acquiescence bias - e.g., the tendency to provide confirming answers in response to survey questions - are both positively correlated with Openness and Conscientiousness using data from the US and Latin America (M. V. Hibbing, Cawvey, Deol, Bloeser, \& Mondak, 2019).

\section{Context}

The majority of the literature discussed in this chapter draws upon samples from people who originate from Western, Educated, Industrialized, Rich and Democratic (WEIRD) countries (Henrich, Heine, \& Norenzayan, 2010). At the same time there are increasingly studies that rely upon samples from other contexts such as Eastern Europe (e.g., Malka, Soto, Inzlicht, \& Lelkes, 2014), Latin America (e.g., Mondak, Canache, Seligson, \& Hibbing, 2011) or Asia (e.g., Beattie, Chen, \& Bettache, 2021; Ha, 2019; Ha, Kim, \& Jo, 2013). Sometimes the data from different contexts have been used to show that personality has robust associations with the political outcome across contexts (Bakker, Schumacher, \& Rooduijn, 2021; Gravelle, Reifler, \& Scotto, 2020; Mondak et al., 2011). In contrast, others use context as a moderator of the association between personality and politics (Malka et al., 2014). More - not less - research should take context into account.

\section{Personality and political ideology}

Early theories of political behavior have put forward that deeper-seated personality traits are essential to understand political ideology (Adorno et al., 1950; Campbell et al., 1960; McClosky, 1958). McClosky (1958, p.40), for instance, explained that people align their perceptions of the world with their "own inner feelings," whereby an "individual creates a set of perceptions that express, or that are consonant with, his own needs and impulses." In support of this claim, McClosky (1958, p.37-38), found that conservatives are more hostile, suspicious, rigid, compulsive, defensive, anxious, and guilt sensitive compared to liberals. These findings lead McClosky (1958, p.28) to conclude there is a "considerable regularity and coherence ... in the relation between 
certain casts of character and personality on the one side and the degree of conservatism or liberalism expressed on the other." Up to today, there is an ever-growing number of studies that continue to provide evidence that the personality traits are associated with political ideology - for a recent review, see (Federico \& Malka, 2018). This literature assumes that citizens adopt ideological positions that provide the best fit with the motives and needs rooted in their personality (Jost, Federico, \& Napier, 2009) - for a recent critique Costello, Clark, and Tetlock (2021).

The Big Five personality traits have been widely used in the study of ideology (for instance, Bakker, 2017; Beattie et al., 2021; Gerber, Huber, Doherty, Dowling, \& Ha, 2010; Mondak \& Halperin, 2008; Sibley et al., 2012; Zmigrod, Eisenberg, Bissett, Robbins, \& Poldrack, 2021). Across samples and contexts, Openness is negatively associated with conservative ideology, whereas Conscientiousness is positively associated with conservative ideology (Sibley et al., 2012). A meta-analysis by Sibley et al. (2012, p. 664) showed that "Openness to Experience $(\mathrm{r}=.18)$ and Conscientiousness $(\mathrm{r}=.10)$ were significantly but weakly correlated with political conservatism". The size of these correlations suggests that the effect is small (Funder \& Ozer, 2019). Explaining these associations, Carney, Jost, Gosling, and Potter (2008, p.825) argued that "left-wingers are more motivated by creativity, curiosity, and diversity of experience, whereas right-wingers are more motivated by self-control, norm attainment, and rule-following."

Traditionally, the unidimensional left-right scale captures support or opposition to social change and support or opposition to government intervention (Jost et al., 2009; Jost, Glaser, Kruglanski, \& Sulloway, 2003). Among the mass public, for most people, ideology consists of (at least) two dimensions (Feldman \& Johnston, 2014; Treier \& Hillygus, 2009): one for cultural policies and one for economic policies. Acknowledging that ideology is multi-dimensional, there is growing evidence that the direction and strength of the association between personality and ideology differ across ideological dimensions (Bakker, 2017; Duckitt \& Sibley, 2010; Feldman \& Johnston, 2014; Gerber et al., 2010).

Generally, the associations between personality traits and cultural conservatism are similar to those reported for left-right ideological self-placement. There is, for instance, pretty consistent evidence that the Big Five trait Openness to Experience is negatively associated with cultural conservatism, while the Big Five trait Conscientiousness is positively associated with cultural conservatism (Ackermann, Ackermann, \& Freitag, 2018; Bakker, 2017; Bakker \& Lelkes, 2018; Duckitt \& Sibley, 2010; Gerber et al., 2010). ${ }^{5}$

Regarding the personality correlates of economic ideology, at least four different perspectives exist. The first perspective suggests no (or a much weaker) resonance between economic ideology and psychological needs. J. R. Hibbing, Smith, and Alford (2014, p.340), for instance, in their review of the literature, conclude that "psychological and biological characteristics are less relevant to economic issues . . . than they are to social issues." There is quite some evidence that traits like Openness and Conscientiousness have a weaker association with economic conservatism or that there

5 The association between personality and anti-immigration attitudes, and prejudice in general, has been widely studied but will not be discussed in detail - see for some recent examples, (Ackermann \& Ackermann, 2015; Brandt, Reyna, Chambers, Crawford, \& Wetherell, 2014; Crawford \& Brandt, 2019; Dinesen, Klemmensen, \& Nørgaard, 2016; Gallego \& Pardos-Prado, 2014; Talay \& De Coninck, 2020; Ziller \& Berning, 2021) - because anti-immigration attitudes are strongly connected to cultural conservatism (see for instance, Caughey, O’Grady, \& Warshaw, 2019). 
is no statistically significant association between personality traits and economic conservatism (for a review see Johnston et al., 2017).

The second perspective follows Mondak and Halperin (2008, p. 339) who argued that "full attention to the possible political significance in [personality] traits will require expanded exploration of possible indirect effects." Malka et al. (2014), for instance, found that those higher on the needs for security and certainty hold more left-wing economic ideology. But this association is weaker as engagement increases. Johnston et al. (2017, p.3) showed that, in the United States, Openness is uncorrelated with economic ideology, but that engagement conditions its relationships. Specifically, Johnston et al. (2017) reported that among those with high levels of engagement, closed-minded citizens (i.e., those low on Openness) tend to gravitate toward conservative (right-wing) economic policies. Conversely, closed-minded citizens with low levels of engagement gravitate toward liberal (left-wing) economic policies.

A third perspective is that some traits - other than Openness, Conscientiousness, and other traits in the Open vs. Closed personality family (Johnston et al., 2017) - correlate with economic ideology. For example, those higher on Agreeableness express support for left-wing economic policies such as a strong welfare state, helping those that need help, and a "big" government who can be trusted to take care of other people (Bakker, 2017; Duckitt \& Sibley, 2010; Gerber et al., 2010). Likewise, neurotic individuals support left-wing economic policies because these policies would accommodate their anxiety and insecurity (Bakker, 2017; Gerber et al., 2010; Van Hiel \& Mervielde, 2004). Finally, outside the Big Five framework, dispositional empathy (Feldman, Huddy, Wronski, \& Lown, 2020) is positively correlated with support for left-wing economic policies.

A fourth perspective suggests that lower-income levels attenuate the association between personality and economic ideology. Lane (1955) argued that among people with lower income levels, support for social welfare "has a quality of self-interest which obscures and overrides the relationship of personality (authoritarianism) to attitudes toward the welfare state". Using population-based samples from Denmark, the United Kingdom, and the United States, Bakker (2017) reports that the association between Agreeableness and economic ideology is indeed weaker among people with a low income compared to people with a higher income.

More research should try to disentangle when the association between personality and economic ideology is direct or conditional upon factors such as engagement. ${ }^{6}$

\section{Moving beyond the Big Five personality traits}

Johnston et al. (2017) argued that ideology is associated with a general dimension of Open vs. Closed personality. Openness is according to Johnston et al. (2017, p. 7) "a general dimension of personality tapping tolerance for threat and uncertainty in one's

\footnotetext{
${ }^{6}$ Foreign policy attitudes and attitudes towards supra-national institutions are relatively independent of cultural and economic conservatism. Across the board there is no real consistent pattern of associations between personality attitudes and different EU attitudes in the published work (Aichholzer \& Rammstedt, 2020; Bakker \& de Vreese, 2016; Curtis, 2016; Curtis \& Miller, 2021; Curtis \& Nielsen, 2018, 2020; Duckitt \& Sibley, 2016; Sagiv, Roccas, \& Hazan, 2012; Schoen, 2007; Tillman, 2013). This inconsistent pattern could be due to differences in the independent and the dependent variable, the time period, the context, or other differences between the studies. It could also mean that personality traits are not linked to attitudes towards supra-national institutions.

Some studies assessed the association between personality and foreign policies, see Gravelle et al.
}

(2020); Mondak (2010); Schoen (2007). 
environment". Closed-minded citizens "prioritize order, certainty, and security in their lives... value tradition, self-discipline, group cohesion, and respect for authority, and... have conventional cultural tastes" (Johnston et al., 2017, p. 7). Open-minded citizens are "attracted to novelty, skeptical of traditional sources of authority, prioritize self-direction and individualism" and have "unique and unconventional tastes and preferences" (Johnston et al., 2017, p. 7). Open vs. Closed personality is captured by the Big Five traits Openness and Conscientiousness but also by Authoritarianism (Feldman, 2003; Feldman \& Stenner, 1997), Need for Closure (Webster \& Kruglanski, 1994), risk-taking (Kam \& Simas, 2012) and openness to change versus conservation (Schwartz, 1992). Johnston et al. (2017) report consistent evidence that those with a more closed personality are more conservative compared to those with a more open personality. These findings align with the results from meta-analyses of traits related to the open vs. closed personality (Jost et al., 2003; Jost, Stern, Rule, \& Sterling, 2017).

The argument by Johnston et al. (2017) is persuasive as it bundles much research on specific traits into an overarching argument. However, recent work also suggests that other personality traits have meaningful correlations with political ideology. There is generally a positive association between Authoritarianism and right-wing ideology (Feldman \& Stenner, 1997; Stenner, 2005; Zmigrod et al., 2021). The HEXACO trait Honesty-Humility correlates negatively with various measures of conservatism (Chirumbolo \& Leone, 2010; de Vries, Wesseldijk, Karinen, Jern, \& Tybur, 2021; Leone, Desimoni, \& Chirumbolo, 2012). The Dark Tetrad traits Narcissism, Psychopathy and Machiavellianism are positively associated with conservatism (see for instance, Hodson, Hogg, \& MacInnis, 2009; Jonason, 2014; Zeigler-Hill et al., 2020) Hatemi and Fazekas (but see, 2018). Finally, Disgust Sensitivity - especially the sensitivity to experience disgust towards pathogens - has been positively associated with conservatism (a uni-dimensional measure). Disgust Sensitivity was also positively associated with culturally conservative policy attitudes such as anti-immigrants attitudes (Aarøe et al., 2017), attitudes towards gay people (Balzer \& Jacobs, 2011) and premarital sex (Smith, Oxley, Hibbing, Alford, \& Hibbing, 2011). ${ }^{7}$ To conclude, there are meaningful correlations between personality traits and ideology beyond the family of Open vs. Closed personality.

\section{(Critical) Reflections on the personality-ideology literature}

This section will reflect on the state-of-the-art in this field, focusing on the role of sample characteristics, context, sub-dimensions, and the assumed causal effect of personality on ideology.

\section{Does the context condition the association between personality ideology?}

A plausible hypothesis is that context conditions the association between personality and ideology. Mondak (2010, p.90) for instance, formulates the expectation that "the expression of personality traits will vary by situation". The "threat-constrained model" suggests that "that personality should be most predictive of behavior when situational

\footnotetext{
${ }^{7}$ Preliminary studies also document individual differences in disgust sensitivity as captured with physiological arousal (i.e., changes in skin conductance levels in response to disgusting images) was positively associated with socially conservative policies Aarøe et al. (2017); Smith et al. (2011). A preregistered and well-powered direct replication failed to find evidence for the existence of an association between physiological disgust sensitivity and socially conservative policy positions.
} 
factors (e.g., extreme social norms or chronic perceptions of the social world) do not inhibit individual tendencies" (Sibley et al., 2012, p. 673). Sibley et al. (2012, p. 673) find support for their model as "increases in nation-wide systemic danger attenuated the relationship between Openness to Experience and political orientation". If the threat in a nation is low, then the association between Openness and conservatism is negative and of modest effect size. Yet, when threat in a country is high, then the association is "trivial" (Sibley et al., 2012, p.674). More evidence for the "threat-constrained model" was documented by Malka et al. (2014) who reported that the association between the Need for Structure and right-wing (conservative) political preferences was stronger in countries with higher levels of human development.

The historical context could also moderate the association between personality and ideology. Malka et al. (2014, p. 1034) explained that "under circumstances in which the historically prevailing ideology is strongly egalitarian, [closed-personality] characteristics might yield preference for economic equality (i.e., left-wing economic preferences). This is because those seeking security and certainty will prefer to keep social and institutional conditions as they have been." In Eastern European countries - compared to other countries - a closed-personality (a high level of the Need for Structure) had a stronger correlation with left-wing economic policy preferences (Malka et al., 2014). Finally, a recent study by Beattie et al. (2021) suggests that patterns of associations between personality and ideology in Western countries do not directly replicate in China. The pattern reverse: "the liberal Right in China mostly evinces traits of the psychological Left in the West, while the "conservative Left" mostly evinces traits of the psychological right in the West". 8

The work by Sibley et al. (2012), Malka et al. (2014) and Beattie et al. (2021) offers some evidence that the association between Openness and conservatism might be conditional upon context. More, not less, research is needed to answer the question of how context conditions the association between personality and ideology.

\section{Do sample characteristics condition the association between personality and ideology?}

Students do not reflect the general population. They are younger, higher educated, and privileged (not always). The consequences of this "narrow subject pool" for political psychology have been well known (Sears, 1986) but see Druckman and Kam (2011). Importantly, across the board, the association between personality and ideology does not seem to be affected by whether the participants in the students were students, members of a local community, workers on Amazon's Mechanical Turk or drawn from the general population (see, S. J. Best, Krueger, Hubbard, \& Smith, 2001; Clifford et al., 2015; Cooper, McCord, \& Socha, 2010; Sibley et al., 2012; Vitriol et al., 2019).

\section{Should research turn to the lower order sub-dimensions of personality?}

Personality traits have lower order sub-dimensions - depending on the specific model of personality per trait two (DeYoung, Quilty, \& Peterson, 2007), three (Soto \& John, 2017), or six sub-dimensions (Costa Jr et al., 1991). Sub-dimensions "offer more nuanced characterizations of the types of motivations and behaviors associated with

\footnotetext{
8 Due to the problems with the WVS measure of personality the findings by Fatke (2017) are not discussed in detail here.
} 
each broad trait" (Xu, Soto, \& Plaks, 2021, p.2). Studies outside of the domain of politics show that the sub-dimensions give important additional information compared to the higher-order traits in predicting a variety of social, emotional, and behavioral outcomes (Denissen, Geenen, Soto, John, \& Van Aken, 2019; Soto \& John, 2017). This supports the conclusion that "much important information can be lost when one's focus on personality is exclusively at the Big Five" traits (Paunonen \& Ashton, 2001, p.85).

The same might be true for the association between personality and ideology. For Openness and Conscientiousness it seems that some, but not all, sub-dimensions are associated with ideology (Aichholzer, Danner, \& Rammstedt, 2018; Carney et al., 2008; Gerber, Huber, Doherty, \& Dowling, 2011a; Van Hiel \& Mervielde, 2004; Xu et al., 2021). These findings suggest that the associations between these traits and ideology might be more heterogeneous than so far assumed.

Facets might also be relevant for another reason. Xu et al. (2021, p.2) explain that "a weak or nonsignificant association between a particular Big Five domain and political orientation may be due to a strong association between one of that domain's lower-level traits and political orientation, but a weak (or even reversed) association between another lower-level trait and political orientation." For example, Agreeableness is not systematically associated with ideology (Sibley et al., 2012). However, when decomposing Agreeableness into the sub-dimensions Compassion and Politeness, then Politeness is positively associated with conservatism, while Compassion is negatively associated with conservatism (Hirsh, DeYoung, Xu, \& Peterson, 2010; Osborne, Wootton, \& Sibley, 2013; Xu et al., 2021). To summarize, the focus upon the trait might hide specific patterns of associations between personality and ideology.

\section{Is personality causing ideology?}

The majority of the research showing evidence for the link between self-reported personality traits and self-reported ideology relies upon cross-sectional research designs. Often these studies explicitly or implicitly assume that personality is the cause and politics the effect. There is, however, less research that disentangles the extent to which personality causes political ideology. Correlation does not imply causation, and the correlation between the traits and political ideology could be spurious or endogenous. The subsequent sections discuss a series of research lines that question whether personality indeed causes political preferences.

Problems with content overlap. Content overlap is the problem that the content of a personality battery overlaps with the content of the ideology measure. This problem has been discussed in detail by Malka et al. (2017). Content overlap could be an issue in the association between Openness and ideology. Openness to Experience in the Five-Factor Model contains a sub-facet called "Openness to Values". Someone low on Openness was described as a person who "favors conservative values" (Costa Jr \& McCrae, 1992, 657). Indeed, Openness batteries can contain items directly tapping into politics such as "Believe that criminals should receive help rather than punishment." in the measures of Openness in the International Personality Inventory Project ( https://ipip.ori.org/newNEOKey.htm\#Liberalism).

Likewise, Agreeableness might also suffer from content overlap. For example, the sub-dimension (facet) Tender-mindedness is measured using items such as "Sympathize with the homeless," and "Believe people should fend for themselves" in the NEO PI-R https://ipip.ori.org/newNEOKey.htm\#sympathy. As such, Agreeableness might have some content overlap with measures of economic conservatism which often ask about 
political such as income redistribution and social welfare policies (Feldman \& Johnston, 2014). To conclude, the risk of content overlap is present, and researchers should be careful about uncovering potentially tautological relationships between personality and ideology.

Studies assessing the reciprocal relationship between personality and ideology. So far, only a few longitudinal studies have more directly addressed whether personality is causing ideology. First, using panel data from Australia (Hatemi \& Verhulst, 2015) and New Zealand (Osborne \& Sibley, 2020) spanning multiple years, no lagged effect of Openness on conservatism was found. Second, Luttig (2021) finds a reciprocal relationship between Authoritarianism and support for the Republican party. Third, Bakker, Lelkes, and Malka (2021) use panel studies in the Netherlands, Germany (preregistered), and the United States (preregistered). They find reciprocal relationships between the Big Five traits Openness and Conscientiousness (Netherlands and Germany) and Authoritarianism (United States) and political ideology. To conclude, at best, the evidence is mixed. And if personality causes ideology, the effects are small (Bakker, Lelkes, \& Malka, 2021; Luttig, 2021).

Why would political ideology influence personality? First, people are aware of the stereotypes that belong to "their" ideological group (Ahler \& Sood, 2018; Rothschild, Howat, Shafranek, \& Busby, 2019). Indeed, people's ideology motivates them to express their personality in a socially desirable or stereotypical manner (Ludeke, Tagar, \& DeYoung, 2016; Ludeke, Weisberg, \& DeYoung, 2013). Second, people surround themselves with politically like-minded others (Boutyline \& Willer, 2017; Huber \& Malhotra, 2017) and could adopt the personality of these politically like-minded others.

Bakker, Lelkes, and Malka (2021) reported that ideology causes Openness and Conscientiousness using panel studies in the Netherlands and Germany and that ideology causes Authoritarianism using a panel study in the United States - see also (Luttig, 2021). Using survey experiments, (Bakker, Lelkes, \& Malka, 2021) also found that the personality traits (Big Five and Authoritarianism) are stronger associated with political ideology - assessed a week before - when the political context is made salient compared to a placebo control condition. These studies provide evidence that personality is causing political ideology and that ideology is also causing personality. The fact that the relationship is reciprocal has at least two implications. First, this means that cross-sectional studies' estimates of the association between personality and ideology could be biased. Second, this suggests that personality is not only the cause of political polarization as is often assumed (see for instance, J. R. Hibbing, Smith, \& Alford, 2013) but also the consequence. As such, polarization effects also non-political outcomes, such as self-reported personality.

Is childhood personality causing adult ideology. One possible design to answer whether personality is causing ideology is a design where the personality of children - before attaining political preferences - is linked to ideology later in life (Landau-Wells \& Saxe, 2020).

Block and Block (2006b) assessed the personality of 95 children from two different nursery schools in the San Francisco Bay Area at both ages three and four. The same respondents reported their political ideology at age 23. Block and Block (2006a) found that conservative adult men were in childhood visibly deviant, felt unworthy and guilty, were easily offended, were anxious when confronted by uncertainties, and were distrustful of others. Likewise, conservative women were as children inhibited, easily victimized, indecisive, fearful, shy, compliant, anxious when confronted by ambiguity, 
and fearful. These correlations lead Block and Block (2006a, p. 12) to conclude that conservatives in adulthood were viewed in childhood "as uncomfortable with uncertainty, as susceptible to a sense of guilt, and as rigidifying when experiencing duress."

Relying upon the National Institute of Child Health and Human Development Study of Early Child Care and Youth Development study in the United States, Fraley, Griffin, Belsky, and Roisman (2012); Wegemer and Vandell (2020) reported two conceptual replications. Childhood personality was measured when children were 54 months old and age 18 and 26 the completed measures of political ideology. Children who had difficulty paying attention had lower levels of activity or restlessness and had higher levels of fearfulness were more conservative in adulthood (Fraley et al., 2012; Wegemer \& Vandell, 2020). However, two conceptual replications by Fasching, Arceneaux, and Bakker (2021) in the United Kingdom - with large samples that were sufficiently powered to detect small effects and one preregistered study - failed to find any indication for a consistent association between childhood personality and adult ideology. To summarize, the evidence for the association between childhood personality and ideology is in its infancy, and the results are mixed.

Evidence from behavior genetics. Research using twin-study designs can partly address the question of whether personality has a casual effect on ideology. A meta-analysis by Hatemi et al. (2014) showed that the genetic influence on ideology accounts for 40 percent of the total variation in ideology. One possibility is that personality is the missing link between genes and ideology. Studies addressing this possibility show that there is a genetic overlap between personality and ideology (Hatemi \& Verhulst, 2015; Kandler, Bell, Shikishima, Yamagata, \& Riemann, 2015; Verhulst, Eaves, \& Hatemi, 2012). Dawes and Weinschenk (2020) explain that the overlap between personality and ideology could mean that: (a) genes influence personality and personality influences ideology; (b) genes could also influence ideology and ideology could influence personality; (c) it could also suggest a reciprocal relationship whereby personality and ideology are both cause and consequence of each other, or (d) the same genetic component influences personality and ideology, but this is happening largely independent from each other. Right now, "additional research is needed to develop a better understanding of the pathways that connect genes to political ideology" (Dawes \& Weinschenk, 2020, p.175)

Is personality causing ideology? The best answer to this question, at this point, is "we don't know". Studies that rely upon panel studies, experiments, cohort studies, and twin-study designs illustrate that the assumed uni-directional effect of personality on ideology requires careful reconsideration. It is safe to say that this is a reconsideration of one of the central research questions in political psychology. More research is needed to solve this question. It won't be easy, and perhaps the outcomes challenge the core assumptions of this literature. However, as Merton (1942) already outlined, scientists need to challenge the foundations of their field.

\section{Personality and voting behavior}

A rich literature in both political science and psychology has assessed the extent to which support for specific political parties correlates with certain personality traits. The dominant assumption in this literature is that ideology mediates the association between personality and vote choice. While the patterns differ a bit across context, measures, and samples, a couple of general patterns can be observed: 
Openness is associated with support for left-wing (liberal) parties in the USA (Barbaranelli, Caprara, Vecchione, \& Fraley, 2007; Cooper, Golden, \& Socha, 2013; Gerber, Huber, Doherty, \& Dowling, 2012; Mondak \& Halperin, 2008; Rentfrow, Jost, Gosling, \& Potter, 2009), United Kingdom (Aidt \& Rauh, 2018), Italy (Capara, Barbaranelli, \& Zimbardo, 1999; Caprara, Schwartz, Capanna, Vecchione, \& Barbaranelli, 2006; Chirumbolo \& Leone, 2010), Germany (Bakker et al., 2015; Riemann, Grubich, Hempel, Mergl, \& Richter, 1993; Schoen \& Schumann, 2007) and New Zealand (Osborne \& Sibley, 2012). A comparative study drawing upon convenience samples from Italy, Germany, Spain, Greece and Poland draws a similar conclusion (Vecchione et al., 2011). Osborne and Sibley (2012, p. 744) show that the association between Openness and voting for left-wing parties is stronger for those with a higher level of political sophistication - who are able "to identify which political party supports the issues that best resonate with their personality".

In line with the research on personality-ideology there is pretty consistent evidence for a positive association between Conscientiousness and support for right-wing parties in a variety of countries in the Western world including, but not limited to, US, UK, Italy, Germany, New Zealand (Aidt \& Rauh, 2018; Bakker et al., 2015; Barbaranelli et al., 2007; Capara et al., 1999; Caprara et al., 2006; Chirumbolo \& Leone, 2010; Cooper et al., 2013; Gerber et al., 2012; Mondak \& Halperin, 2008; Osborne \& Sibley, 2012; Rentfrow et al., 2009; Riemann et al., 1993; Schoen \& Schumann, 2007; Vecchione et al., 2011).

Agreeableness and Neuroticism also show pretty consistent positive associations with support for left-wing political parties - i.e., higher agreeable and/or higher neurotic people are more supportive of left-wing parties (Aidt \& Rauh, 2018; Bakker et al., 2015; Barbaranelli et al., 2007; Capara et al., 1999; Caprara et al., 2006; Chirumbolo \& Leone, 2010; Cooper et al., 2013; Gerber et al., 2012; Mondak \& Halperin, 2008; Osborne \& Sibley, 2012; Rentfrow et al., 2009; Riemann et al., 1993; Schoen \& Schumann, 2007; Vecchione et al., 2011; Wang, 2016).

Outside the Big Five, the HEXACO trait honest-humility correlates positively with support for left-wing parties Chirumbolo and Leone (2010). When it comes to the dark personality traits, Nai, Maier, and Vranić (2021) conclude that "voters that themselves score higher on "dark" personality traits (Narcissism, Psychopathy, Machiavellianism) tend to like dark candidates". Finally, in a series of studies in the United States and Denmark, Aarøe, Petersen, and Arceneaux (2020) find that those higher on pathogen disgust - a dimension of Disgust Sensitivity - vote for socially conservative political parties.

Some studies explicitly test the mediation argument that the association between personality and voting behavior is mediated by ideology (or core political values). Schoen and Schumann (2007), for instance, showed that in Germany, the association between personality and vote choice is mediated by factors such as party identification, ideology, postmaterialism, and materialism as well as specific policy preferences. Schoen and Schumann (2007, p. 492) explain that this shows "how deep-seated personality traits can be linked to partisan feelings and vote choice in theoretically consistent ways: They influence predispositions and attitudes that in turn affect opinions about political parties and vote choice." As such personality "influence[s]" vote choice "indirectly rather than directly" (Schoen \& Schumann, 2007, p. 492). Along the lines of (Schoen \& Schumann, 2007), Wang (2016, p. 32) concludes that in the US:

"higher levels of extraversion, conscientiousness, and emotional stability 
indirectly decrease the probability of voting for Obama by weakening individual Democratic identification, triggering negative feelings toward the Democratic candidate, preferring the policy of the Republican Party, and possessing negative evaluations of presidential performance. By contrast, higher levels of openness to experience indirectly increase the probability of voting for Obama by strengthening individual Democratic identification, triggering positive feelings toward the Democratic candidate, preferring the policy of the Democratic Party, and possessing positive evaluations of presidential performance."

The idea that ideology mediates the association between personality and vote choice is persuasive, however, it is not uncontested. First, in cross-sectional survey designs, upon which most studies rely, it is impossible to disentangle the causal ordering of the variables. One might wonder whether ideology is indeed causally prior to vote choice as vote choice is endogenous to political ideology (e.g., Harteveld, Kokkonen, \& Dahlberg, 2017; Rooduijn, Van Der Brug, \& De Lange, 2016), core political values (McCann, 1997), as well as party and leader evaluations (Bølstad, Dinas, \& Riera, 2013; Mullainathan \& Washington, 2009). Personality might also be endogenous to political ideology (Bakker, Lelkes, \& Malka, 2020; Luttig, 2021) and approval of political parties and candidates (Boston et al., 2018). Even if the causal ordering is correct, it is methodologically hard, if not impossible, to get an unbiased estimate of a mediation effect (Bullock, Green, \& Ha, 2010). The next generation research should move beyond cross-sectional study designs and disentangle the relationship between personality, ideology, and vote choice.

\section{Different perspectives on personality and vote choice: the case of voting for populist parties}

The dominant perspective, the "mediation hypothesis" (discussed in the previous section), is that ideology mediates the association personality and vote choice. However, the "resonance-hypothesis" is an alternative perspective that explains the link between personality and vote choice. This hypothesis builds upon the idea that politicians speak the language of the personality of their voters. In particular, Caprara and Zimbardo (2004, p. 584) argued that "a crucial skill for politicians is ... to speak the language of personality" of their electoral base. According to this model, the congruence between personality and the political message leads to a vote choice. Along these lines, the "differential susceptibility to media effects model" in communication puts forward that the content of a message is appreciated by some, but not by others and that this is dependent on personality (Valkenburg \& Peter, 2013).

The literature on personality and voting for populist parties tests the "mediation hypothesis" and the "resonance hypothesis". It is, therefore, essential to define populism. Populists communicate an anti-establishment message (e.g., elites in The Hague are evil, corrupt, and working for their gain) combined with a message the places the people central (e.g., politicians are disinterested in the common Dutch people) (Canovan, 1981; Mudde, 2004). The anti-establishment message and people-centrist message that units all populists, while their ideology distinguishes populists: they can, for instance, be left-wing, right-wing, or centrists.

First, evidence for the "mediation hypothesis" is provided in studies that link Authoritarianism with populism. Authoritarians prefer social order, structure, and 
obedience. It is not clear why Authoritarianism would be receptive to the anti-elitism message of populists. Yet, Authoritarianism is positively associated with support for populist politicians with a right-wing host ideology (Arceneaux \& Nicholson, 2012; Bakker, Rooduijn, \& Schumacher, 2016; Bakker, Schumacher, \& Rooduijn, 2021; Dunn, 2015). More conclusive support for the argument that Authoritarianism is associated with a vote for populists via the host-ideology of some (right-wing) populist politicians was provided by Bakker, Schumacher, and Rooduijn (2021). In their conjoint experiment Bakker, Schumacher, and Rooduijn (2021) show that among high authoritarian citizens, an anti-immigration message increases support for politicians compared to pro-immigration messages. However, the anti-establishment message does not persuade those higher on Authoritarianism. Second, a series of studies provide evidence for the resonance hypothesis. Specifically, the anti-establishment message of populist politicians portrays elites as evil, corrupt and self-centered. The anti-establishment message should resonate with those lower on Agreeableness who shy away from conflict (Skarlicki, Folger, \& Tesluk, 1999), are cynical, uncooperative, and distrusting of others (Costa Jr et al., 1991). Indeed, those lower on Agreeableness are more supportive of populists with nationalist and exclusionist ideology such as Donald Trump (Abe, 2018; Bakker, Schumacher, \& Rooduijn, 2021; Fortunato, Hibbing, \& Mondak, 2018), the Tea Party (Bakker, Rooduijn, \& Schumacher, 2016; Bakker, Schumacher, \& Rooduijn, 2021), the Austrian FPO (Aichholzer \& Zandonella, 2016), the Swiss SVP (Ackermann, Zampieri, \& Freitag, 2018; Bakker, Schumacher, \& Rooduijn, 2021), and Marine Le Pen in France (Vasilopoulos \& Jost, 2020). ${ }^{9}$ But the associations between Agreeableness and voting for populist parties also occurs when populists have a left-wing ideology such as Die Linke (Germany), Podemos (Spain), or Chaves (Venezuela) (Bakker, Rooduijn, \& Schumacher, 2016; Bakker, Schumacher, \& Rooduijn, 2021). ${ }^{10}$.

All the discussed studies correlated Agreeableness with the populist vote and can, by design, not address whether it is indeed the populist rhetoric that is congruent with low Agreeableness as the resonance-hypothesis suggests. In a conjoint-experiment in the United States, Bakker, Schumacher, and Rooduijn (2021) addressed the proposed resonance directly. They measured Agreeableness and afterward let participants vote in a series of mock elections between two politicians. An anti-establishment message or a pro-establishment message was randomly assigned to each politican. At the same time the conjoint-experiment allowed Bakker, Schumacher, and Rooduijn (2021) to vary the host-ideology of the politicians. Indeed, the anti-establishment message leads to more support for a politician among the low agreeable voters. This experiment provides direct evidence that a message congruent with a person's personality leads to more support for the politician.

\footnotetext{
${ }^{9}$ Other studies have relied upon populist attitudes instead of populist vote. The association between Agreeableness and populist attitudes is less consistent (Fatke, 2019; Galais \& Rico, 2021; Pruysers, 2020). Yet, populist attitudes and vote choice are not equivalent (Akkerman, Mudde, \& Zaslove, 2014). Some people who express populist attitudes don't vote for populist parties and vice versa. Moreover, there is an ongoing discussion about the measurement and validity of populist attitudes (Castanho Silva, Jungkunz, Helbling, \& Littvay, 2020; Wuttke, Schimpf, \& Schoen, 2020). The use of different measures of populist attitudes leads to different conclusions about the psychological correlates (Erisen et al., 2021).

10 Vasilopoulos and Jost (2020) do not find this pattern when it comes to Melanchon - a left-wing populist.
} 
To summarize, the literature on personality and populist vote demonstrates two routes from personality to vote choice. One via the host-ideology as the mediation hypothesis suggests and one via the resonance between the populist message and personality as the resonance hypothesis suggests. The personality-populism literature is just an illustration of the two possible links between personality and vote choice. More research addressing if and how personality is associated with vote choice will bring the field closer to understanding the role of personality in the voting booth.

\section{Personality and the strength of political loyalties}

Personality might also be associated with the strength of political loyalties captured in the strength of political partisanship and electoral volatility.

In the domain of politics, extraverts discuss politics more often, participate in political campaigns (Mondak \& Halperin, 2008) and are committed to organizations (Erdheim, Wang, \& Zickar, 2006). In addition, extraverts have a stronger partisanship (Bakker et al., 2015; Gerber et al., 2012). Moreover, in Denmark, but not in the UK, extraverts are more likely to stay loyal to their party over time (Bakker, Klemmensen, et al., 2016). This null finding in the UK could be due to the highly abbreviated measure of personality used in the UK sample.

The curiosity, open-mindedness, and willingness to try new activities should make those higher on Openness less likely to commit to a party. Gerber et al. (2012) found a negative association between Openness and the strength of party identification. Relying upon multi-wave panel studies, Bakker, Klemmensen, et al. (2016) documented that in Denmark and the UK, those higher on Openness to Experience are more likely to change their vote choice between subsequent elections. ${ }^{11}$ Further support for the idea that the open-minded are less likely to commit to political parties comes from the research on related traits, such as the Need for Cognition and risk-taking. Those who enjoy thinking and are open to ideas - as indicated by a higher score on the Need for Cognition - tend to have more ambivalent partisanship (Rudolph \& Popp, 2007). Kam and Simas (2012) showed that those who take more risks vote for the challenger candidate.

Conscientious people prefer order, adhere to social norms, plan and organize tasks, control impulses, are goal-oriented, and are reluctant to change. These characteristics could make those higher on Conscientiousness strongly identify with a party. Indeed, Gerber et al. (2012) found a positive association between Conscientiousness and the strength of party identification. This finding is consistent with Bakker et al. (2015) who, in one of two tests, reported a positive association between Conscientiousness and stronger party identification. Yet, Bakker, Klemmensen, et al. (2016) found no association between Conscientiousness and the tendency to stay loyal to a party over time.

Agreeable citizens might identify with their in-group as they are attracted by the "communal and cooperative components" of group identification (Gerber et al., 2012, p.661). One might expect that the more agreeable respondents are stronger affiliated with political parties, but the empirical evidence is mixed. Gerber et al. (2012) reported a positive association between Agreeableness and the strength of party identification, while Bakker et al. (2015) found a negative and significant association in 2004 and a negative but insignificant association in 2009. Moreover, Bakker, Klemmensen, et al.

${ }^{11}$ But Bakker et al. (2015) found that those higher on Openness have a stronger party identification. 
(2016) did not find any meaningful association between Agreeableness and the stability of vote.

Neurotic individuals are prone to experience anxiety, anger, and depression. They also tend to feel vulnerable and have a heightened level of self-consciousness. Neurotic individuals might find shelter in the identification with a group. Yet, Neuroticism seems unrelated to the strength of partisanship (Bakker et al., 2015; Gerber et al., 2012) or party loyalty (Bakker, Klemmensen, et al., 2016).

To conclude, the evidence discussed here suggests that Extraversion and Openness are the traits most consistently associated with the strength of political loyalties.

\section{Personality and political engagement}

Political engagement has various dimensions ranging from actual behavior - such as voting or protesting - to attitudes such as internal and external political efficacy. This section briefly reviews the evidence from a systematic literature review - including 56 independent samples - that was recently performed by Bromme et al. (2022) on the relationship between the Big Five personality traits and various aspects of political engagement.

Political involvement. In their review of the literature on political involvement which contains measures of political interest, internal political efficacy, as well as political participation - Bromme et al. (2022), find some consistent patterns. The majority of the studies show that Openness is positively associated with political participation. There were "positive correlations between Openness and political involvement in $84 \%$ of the cases (Bromme et al., 2022, p. 19). Likewise, Extraversion is positively associated with political participation as they document "positive correlations in $71 \%$ of the cases " (Bromme et al., 2022, p. 19). When it comes to

Conscientiousness, it seems that a small majority of the studies report a positive and statistically significant correlation between the trait and political interest as well as internal political efficacy. For political participation, the evidence is mixed: "one study revealed a positive correlation (4\%), while $33 \%$ of the correlations were negative" and the rest was not statistically significant (Bromme et al., 2022, p. 19). A majority of the studies find a negative association between Neuroticism and political interest and between Neuroticism and internal political efficacy. The association between Neuroticism and political participation is less consistent: some negative associations, some positive but most of the associations are not statistically significant. Finally, for Agreeableness, the pattern was inconclusive.

As is relevant in all personality and politics literature, it is important to consider the implied (or assumed) causal nature where personality causes involvement. The studies are cross-sectional and don't allow for a test of the causal relationship. Political involvement is at least partly heritable (e.g., Arceneaux, Johnson, \& Maes, 2012; Klemmensen, Hatemi, Hobolt, Petersen, et al., 2012; Klemmensen, Hatemi, Hobolt, Skytthe, \& Nørgaard, 2012) and Mondak, Hibbing, Canache, Seligson, and Anderson (2010) have argued that personality traits could mediate the relationship between the biological factors and political participation. Some studies have been able to test the argument that personality traits are indeed mediators of this association utilizing twin-study designs. Using two samples from the US Weinschenk and Dawes (2017, p.475) conclude that "most of the relationship between personality and political interest can be explained by the same set of genes" (see also, Dawes et al., 2014; Weinschenk et 
al., 2019). However, more research is needed to determine what this association means (see, Dawes \& Weinschenk, 2020).

Political trust. When it comes to trust in politicians, trust in political institutions and external political efficacy Bromme et al. (2022) find that "for Neuroticism, 53\% of the correlations were negative" and "for Agreeableness, $57 \%$ of the correlations were positive." The correlations between political trust and the other three Big Five traits yielded predominantly null findings. The literature on Agreeableness and trust might suffer from potentially content-overlap. Agreeableness contains a lower order facet "Trust" which captures "the tendency to attribute benevolent intent to others; distrust as the suspicion that others are dishonest or dangerous" (Costa Jr et al., 1991, p. 888). It is not surprising - and perhaps tautological - that Agreeableness correlates with trust in political actors.

\section{Personality and news consumption}

The use of mass media and the selection of the specific outlet is - for most citizens part of their daily routines. Generally, people seek out news "that reflects and reinforce aspects of their personalities" (Rentfrow, Goldberg, \& Zilca, 2011, p. 250). The selection of news that resonates with their personality should occur "irrespective of the medium through which it is conveyed" (Rentfrow et al., 2011, p. 250). This paragraph discusses the associations between personality traits and the types of news consumption, irrespective of the medium.

News can be divided in hard news and soft news (Esser et al., 2012; Reinemann, Stanyer, Scherr, \& Legnante, 2012). Hard news addresses "coverage of breaking events involving top leaders, major issues, or significant disruptions in the routines of daily life, such as earthquake or airline disasters" (Patterson, 2000, p.4). Interview/news shows, news magazines, news programs on TV, and daily newspapers deliver hard news (Baum, 2003; Boukes, Boomgaarden, Moorman, \& De Vreese, 2014). Soft news is "typically more sensational, more personality-centered, less time-bound, more practical, and more incident-based than other news" (Patterson, 2000, p.4). Moreover, soft-news is "personal and familiar in its form of presentation and less distant and institutional" (Patterson, 2000, p.4). Accordingly, entertainment programs and tabloid newspapers bring soft news (Baum, 2003; Boukes et al., 2014).

Extraverts are more interested in politics and discuss politics more often (Gerber, Huber, Doherty, \& Dowling, 2011b; Mondak \& Halperin, 2008). In order to be informed about politics and to foster political discussions, extraverts consume more news (Gerber et al., 2011b; Rentfrow et al., 2011; Trilling \& Schoenbach, 2013). In particular hard news might be appealing as extraverts need "information on recent events for use in subsequent social discussions or talks with others" (Shim \& Paul, 2007, p. 291) in order "to ensure that they are not left out of conversations" (Mondak, 2010, p. 94).

Preliminary evidence in the US suggests that extraverts watch more national news shows - which provide immediate information about the current events in the world (Gerber et al., 2011b; Mondak \& Halperin, 2008). Extraverts also watch more political talk shows - which are generally covering hard news - because they are social and focus upon interpersonal exchange between people (Gerber et al., 2011b).

Openness is positively associated with the consumption of news (Xu \& Peterson, 2017) via television (Gerber et al., 2011b) and newspapers (Finn, 1997; Mondak \& Halperin, 2008) but see (Gerber et al., 2011a). Beyond the general news consumption, Openness is positively associated with a preference for hard news such as informative 
television programs (Kraaykamp \& Van Eijck, 2005) and television news (Gerber et al., 2011b). Yet, the evidence is not conclusive as others found no association between Openness and television news (Mondak \& Halperin, 2008) or between Openness and exposure to other sources of hard news such as political talk shows, daytime talk shows, late night shows (Gerber et al., 2011b). When it comes to soft-news, open-minded citizens express a lower preferences for amusements programs '(Kraaykamp \& Van Eijck, 2005) and watch less amusement programs (Xu \& Peterson, 2017) but read books and watch movies (Finn, 1997). Moreover, open-minded citizens report to have a preference a preference for cultural television programs (Kraaykamp \& Van Eijck, 2005) and watch alternative films, books and television programs (Xu \& Peterson, 2017).

The associations between other traits and news consumption are less clear-cut. Some studies reported a positive association between Neuroticism and a preference for informative TV programs (Weaver III, 1991) as well as the exposure to talk shows on TV (Gerber et al., 2011b; Shim \& Paul, 2007). The findings suggest that Neuroticism is positively associated with news consumption to escape negative feelings and alleviate positive affect. Alternatively, Neuroticism could be negatively associated with news consumption because the conflictual nature of politics could create more negative affect. However, most studies fail to find empirical evidence for the association between Neuroticism and the consumption of news (Finn, 1997; Gerber et al., 2011b; Mondak, 2010; Mondak \& Halperin, 2008; Shim \& Paul, 2007).

There is no evidence that Agreeableness should be associated with consumption of news (Finn, 1997; Gerber et al., 2011b; Mondak, 2010; Mondak \& Halperin, 2008). Evidence is mixed and inconsistent when moving beyond the measures of general news consumption. Agreeableness was unrelated with a preference for informative (i.e., news) programs in the Netherlands (Kraaykamp \& Van Eijck, 2005), while in the US, agreeable citizens might watch more television news and television talk shows during the day but not in the evenings (Gerber et al., 2011b) - but see (Mondak \& Halperin, 2008).

To summarize, Extraversion and Openness seem relatively consistent correlates of news consumption.

\section{Personality of politicians and their political behavior}

\section{Studying the personality of politicians}

There is increasing attention to studying the personality of political elites. Generally, there are three approaches used to study their personality. First, elite surveys in which politicians complete a survey. Elite surveys follow roughly the same approach as most of the work focused upon citizens: politicians receive a survey - via email, regular mail, or in a face-to-face conversation - and complete this survey. This approach has advantages: the research design aligns with the broader personality-politics literature, relies upon validated measures of both personality and politics, and politicians can participate whenever they want. However, there are also downsides and risks of this approach. The response rates of these surveys differ quite dramatically across studies: from only $4 \%$ (Hanania, 2017) and 10\% (Caprara, Barbaranelli, Consiglio, Picconi, \& Zimbardo, 2003) to 33\% (Schumacher \& Zettler, 2019) and even 46.3\% (Nørgaard \& Klemmensen, 2019). The context, the goal of the study, the network of the researchers (are they well connected with politicians), incentives, and other unknown differences between the research designs could explain the origins of the differences in these response rates.

Another point of attention is the measurement of personality. Politicians are busy, 
and their time is valuable. Often, the personality measures are part of a larger omnibus study with many different other measures. As such it common, and justifiable (Gosling et al., 2003), that studies rely upon highly abbreviated measures of personality with only 1 (Dietrich, Lasley, Mondak, Remmel, \& Turner, 2012) or 2 items (Joly, Soroka, \& Loewen, 2019; Scott \& Medeiros, 2020) per trait. At the same time, the use of highly abbreviated measures negatively affects the predictive validity (Bakker \& Lelkes, 2018; Credé et al., 2012). It is therefore a positive development that studies also measured personality with 4 (Schumacher \& Zettler, 2019), 10 (Caprara et al., 2003; Hanania, 2017) or even 12 items (Francescato, Lauriola, Giacomantonio, \& Mebane, 2020; Nørgaard \& Klemmensen, 2019) per trait.

A second approach to study the personality of elites is to let experts - political scientists, psychologists, historians - evaluate the personality of politicians. This is possible as personality ratings of people who are very familiar with the person - a partner, family member, or close friend - are strongly correlated with the personality ratings of the person (Costa \& McCrae, 1988). For instance, relying upon a sample of political scientists with expertise in elections and/or political psychology (Nai \& Maier, 2018) or psychologists (Visser, Book, \& Volk, 2017) studies acquired scores on the Big Five personality traits of Hillary Clinton and Donald Trump - the two primary candidates in the 2016 US Presidential elections.

Relying upon expert ratings, researchers can go back in time and get scores of the personality of politicians who are now dead (see for instance, Rubenzer, Faschingbauer, \& Ones, 2000). Moreover, researchers can get measures of the personality of the most prominent politicians who would, most likely, not participate in their survey or commit to an interview. However, there are also pitfalls. The political ideology of expert raters correlates with the personality assessment of the politicians (Wright \& Tomlinson, 2018). Liberal expert raters evaluated the personality of Trump more extreme compared to more ideologically moderate expert raters (Wright \& Tomlinson, 2018). This lead Wright and Tomlinson (2018, p. 24) to "caution against interpreting expert personality ratings of political candidates when the samples of experts are politically imbalanced" - for a response to this critique see Nai and Maier (2019).

A third approach to study the personality of elites is to rely upon computational methods to get an estimate of politicians' personalities based upon their speeches (Hall, Hollibaugh, Klingler, \& Ramey, 2021; Klingler, Hollibaugh, \& Ramey, 2019; Ramey, Klingler, \& Hollibaugh, 2019; Ramey, Klingler, \& Hollibaugh Jr, 2017). Using computational methods has advantages: it is unobtrusive, it doesn't cost politicians any time, researchers can get scores of the personality of all politicians they want to study, can go back into time, and they don't need to worry about response rates or social desirability bias in the survey responses. At the same time, there are also pitfalls. Politicians have speech writers who write their speech, and it is unclear if and how this affects the measure of personality derived upon the speeches (Schoonvelde, Schumacher, \& Bakker, 2019). Moreover, politicians might "act" in a certain way when giving speeches or debating with other politicians. This public act might differ from their actual personality and bias the derived personality scores in unknown ways.

Rice, Remmel, and Mondak (2021) assessed the correlation between measures of the personality of the same politicians derived upon computational methods and scores from their staffers. They found that the two measures are very weakly related to each other. This raises concerns about the concurrent validity of the measures of elite personality: do different measures of elite personality capture the same construct? More 
research is needed that assesses the validity of measures of elite personality

\section{(Preliminary) Results from studies on the personality of politicians}

Whether the personality of elites differs from the general population is a question that a series of recent studies tackle. Most studies, relying upon self-reported personality of politicians, reported that politicians (elected members of parliament) in Denmark (Nørgaard \& Klemmensen, 2019; Schumacher \& Zettler, 2019), Germany (H. Best, 2011), Italy (Caprara et al., 2003), Canada (Scott \& Medeiros, 2020) and the United States (Hanania, 2017) scored higher on Extraversion compared to ordinary citizens. ${ }^{12}$ Moreover, these studies found - with the exception of Italy - that MPs scored higher on emotional stability (reverse coded Neuroticism) compared to ordinary citizens. ${ }^{13}$

When it comes to whether personality is associated with the ideology or partisanship of politicians, the evidence is mixed. Across the studies that there is no clear pattern of associations between personality and ideology (Caprara et al., 2003; Dietrich et al., 2012; Joly, Hofmans, \& Loewen, 2018; Nai \& Martinez i Coma, 2019; Nørgaard \& Klemmensen, 2019; Rice et al., 2021; Schumacher \& Zettler, 2019; Visser et al., 2017). Differences in personality measurement, response rates, context, and other known and unknown differences in the research design could explain these differences. More comparative studies should address the extent to which politicians' personalities differ across ideological lines.

Personality might also correlate with the behavior of politicians inside and outside parliament. Personality could, for instance, be associated with the ambitions to run for office. Indeed, using self-reported measures of personality, those higher on Extraversion and Openness were more likely to aspire to a career in politics (Blais \& Pruysers, 2017; Dynes, Hassell, \& Miles, 2019). Using a similar research design, Dietrich et al. (2012) documented that US legislators higher on Extraversion are more interested in running for a higher office.

Personality could also be associated with electoral success. Here the evidence is mixed. Politicians who score lower on Agreeableness, compared to those higher on Agreeableness, have more electoral success: they get more votes, stay longer in office, and achieve higher ranks in their party (Joly et al., 2019) but not in a sample of local Canadian politicians (Scott \& Medeiros, 2020). Instead, Scott and Medeiros (2020) finds that higher levels of Openness, Extraversion, and Emotional stability are positively associated with an increased chance of winning an election. Nai (2019), using expert ratings of personality, report that Extraversion is negatively associated with electoral success, while Conscientiousness and that Psychopathy, part of the Dark Tetrad, were positively associated with electoral success.

Finally, personality could be associated with behavior in parliament. In US Congress, those higher on Conscientiousness "propose fewer ceremonial/symbolic bills, instead [of] dedicating their energies to [a] more substantive arena" (Ramey et al., 2017, p. 177). Those higher on Agreeableness have fewer leadership positions in the US Congress, introduce fewer bills, and support more bipartisan bills (Rice et al., 2021). Finally, Extraverts have more leadership positions and support less bipartisan bills (Rice et al.,

\footnotetext{
${ }^{12}$ It is noteworthy that comparing Danish local politicians to higher-level bureaucrats the differences in personality traits are much smaller (Florczak, Ludeke, Klemmensen, Nørgaard, \& Arends, 2020).

13 Note thatScott and Medeiros (2020) report that local Canadian politicians score higher on Openness compared to the population.
} 
2021). Across the board the traits Openness, Conscientiousness and Neuroticism are unrelated to congressional behaviors (Dietrich et al., 2012; Ramey et al., 2017; Rice et al., 2021). In all these studies, personality was correlated with many possible behaviors, increasing the risk of chance findings.

\section{Future Directions: big questions and a call for the adoption of open science practices}

Theoretically, many studies discussed in this chapter assume that personality is causing all sorts of political "outcomes". By design, the cross-sectional research designs that make up most of the personality-politics literature do not allow for causal interpretations. Moreover, recent studies in the personality-ideology question whether personality is causing ideology (Hatemi \& Verhulst, 2015; Osborne \& Sibley, 2020) or whether the pattern is reciprocal (Bakker, Lelkes, \& Malka, 2021; Luttig, 2021). Future research needs to address the theoretical puzzle in recent studies: is personality causing political outcomes? Answering this question will require the design of studies that allow researchers to disentangle the relationship between personality and politics. No one design will provide the definitive answer, but there are underused possibilities such as:

- Studies that rely upon behavioral indicators of personality (Carney et al., 2008; Koppensteiner, 2011). Doing so would solve the problem of correlating self-reported personality with self-reported political constructs and avoid the problem of content overlap (Malka et al., 2017).

- Panel studies that run over longer time periods allow researchers to assess whether personality is causing the political outcome of interest or whether the pattern is reciprocal.

- (Multi-wave) survey-experiments, or other types of experiments, in which politics or personality are manipulated or made more salient (see for instance, Bakker, Lelkes, \& Malka, 2021). These designs allow researchers to get causal control over one (or both) of the concepts.

- Genetically informed samples with measures of both personality and politics can assess the extent to which a shared genetic component underlies personality and politics (Dawes \& Weinschenk, 2020).

A second open question facing the personality-politics literature is whether the associations between personality and politics are direct or indirect. That personality could interact with other factors in the environment has been long recognized (Mischel \& Shoda, 1995). Mondak and Halperin (2008, p. 339), for instance, argued that "full attention to the possible political significance in [personality] traits will require expanded exploration of possible indirect effects." There are at least two possible "indirect" associations.

First, another concept could mediate the association between personality and the political outcome of interest. Ideology could mediate the association between personality and vote choice (Schoen \& Schumann, 2007; Wang, 2016). It is tempting to conceptualize a mediation effect, but it requires a strict causal ordering of the concepts of interest. Recent studies question whether personality is indeed causally prior to ideology and vote choice Bakker, Lelkes, and Malka (2021); Boston et al. (2018); Luttig 
(2021). Moreover, mediation analyses are challenging, if not impossible, to reliably establish (Bullock et al., 2010).

Second, as Mondak (2010, p.90) explains, "the expression of personality traits will vary by situation". Indeed context conditions the association between personality and ideology (Malka et al., 2014; Sibley et al., 2012). Others suggest that individual differences in a third moderating variable condition the association between personality and politics (Bakker, 2017; Johnston et al., 2017).

More research should theorize and test whether the associations between personality and political outcomes are direct and when they are indirect. It will require precise theorizing and the design of suitable studies to test the question of interest. Preregistration of studies will add to the credibility of the literature. This leads to the last point of this chapter: a call for the adoption of open science practices in the personality and politics literature.

\section{A call for the adoption of open science practices}

The remainder of the discussion makes the case to adopt open science practices. Most of the studies covered in this chapter have not adopted open science practices such as systematic reviews of the literature, open data and materials, replication, and preregistration. This section will discuss four changes the field could make moving forward.

1. Share data and materials. Sharing data means researchers make the data they collected publicly available in a repository (Bowman \& Spence, 2020). However, sharing data and materials does not seem to be a common practice as long as journals don't mandate this, see for instance Elson and Przybylski (2017). When researchers share their data and materials on their personal (or institutional) web page, the access to the data quickly disappears as the URL stops working (Gertler \& Bullock, 2017). Sharing data and materials facilitates an open exchange where other researchers directly access the underlying evidence. As such, sharing of data and materials aligns with communality, one of the core values of science as defined by Merton (1942). Communality, according to Merton (1942), holds that sharing of evidence, discussion and open exchange is what defines science. Providing access to data and materials will facilitate an open exchange. Going forward, researchers should, whenever possible, make their data and materials publicly accessible and guarantee they do this following the principles of FAIR - Findable Accessible Interoperable and Reusable - data.

At the same time, data sharing is not always possible. Sometimes data is not collected by the authors, and user agreements prevent researchers from sharing data, see for instance Bakker, Lelkes, and Malka (2021); Bakker, Schumacher, and Rooduijn (2021). Other times, privacy concerns prevent researchers from sharing their data (Bowman \& Spence, 2020). These are legitimate reasons for not sharing data. Yet, in these instances, researchers could make explicit why data cannot be shared and, ideally, how the access could be provided by sharing a data processing agreement.

2. Replication of Results. Replication is the process where a researcher - or a team of researchers - tries to replicate a published finding "by duplicating the methodology as exactly as possible" (Chambers, 2019, p.48). Replication is essential as it provides the empirical evidence that informs theories in the personality-politics literature and allows us to test the foundational claims in the literature (Chambers, 2019). Replications differ in the extent to which they are more direct - following the original procedures and analysis as closely as possible - or more conceptual - testing 
the same underlying idea (Brandt, IJzerman, et al., 2014). In a recent large replication project in the personality literature, Soto (2019) finds that the literature on personality and a host of non-political outcomes is relatively robust and replicable. On the other hand, research in the social sciences shows that the replicated effects are often much weaker than those published in the original studies (e.g., Camerer et al., 2018).

Scholars engaging in replications could consider two things. Following Nuijten, Bakker, Maassen, and Wicherts (2018) they could verify the original results of the study they want to replicate and test the robustness of these results. If the reproduction of findings is not successful, then it is, according to Nuijten et al. (2018), not worth trying to replicate the finding using a different sample. Moreover, if alternative modeling strategies show the association is not robust, then it is not worth engaging in replication (Nuijten et al., 2018). Second, scholars could preregister their replication and document all their decisions before collecting and analyzing the data (see next point) - for example, see Bakker, Schumacher, Gothreau, and Arceneaux (2020). The "replication recipe", developed by Brandt, IJzerman, et al. (2014), is a template that stimulates researchers to think about all possible research decisions in advance.

3. Preregistration. Preregistration means that researchers outline and register their hypotheses, design, and analysis plan, generally, before data collection (Nosek, Ebersole, DeHaven, \& Mellor, 2018). Why is this important? The "credibility crisis" in psychology has shown that researchers chase p-values, post-hock theorizes, and selectively report findings that "worked". Questionable research practices are widespread in psychology (Franco, Malhotra, \& Simonovits, 2016), political science (Franco, Malhotra, \& Simonovits, 2015) as well as other social science disciplines such as communication (Bakker, Kokil, Dörr, Fasching, \& Lelkes, 2021). Studies that are derived using these and other, "questionable" research practices have a small chance of replicating (Asendorpf et al., 2013; Simmons, Nelson, \& Simonsohn, 2011) and impact the credibility of the field (Anvari \& Lakens, 2018). Preregistration safeguards, at least partially, against some of these more questionable research practices such as p-hacking and HARKing.

P-hacking is the process where conscious and unconscious modeling lead people to arrive at a p-value just below .05 - the commonly accepted threshold for statistical significance (Gelman \& Loken, 2014). In the personality-politics literature, p-hacking could occur as a researcher has to decide to adjust for covariates or not, account for measurement error or not, account for missing data or not, etc. Preregistration invites researchers to be explicit about their modeling decisions before data collection and prevents, at least partly, that conscious or unconscious modeling decisions affect the results.

Presenting posthoc findings as if they were predicted from the start is known as Hypothesizing After the Results are Known (HARKing, Kerr, 1998). HARKing is a research practice that was, for generations, considered acceptable and recommended practice. For instance, in the primer on writing a "good" scientific journal article Bem (1987, p. 172) explain: "There are two possible articles you can write: (a) the article you planned to write when you designed your study or (b) the article that makes the most sense now that you have seen the results. They are rarely the same, and the correct answer is (b)." Option (b) is acceptable when researchers are transparent that the interpretation is posthoc and the findings are exploratory. However, option b becomes problematic if exploratory findings are presented as expected from the start (Vermeulen \& Hartmann, 2015). The personality-politics literature could be vulnerable 
to HARKing: expectations are not very specific, and researchers often correlate multiple traits with an outcome variable. At the same time, researchers might not always have a priori expectations about all of them. Preregistration forces researchers to be explicit about what were predictions from the start and what came up later (Nosek et al., 2018).

Once researchers start preregistering their studies, it is also important to carefully consider the sample size requirements. Many of the associations between personality and politics discussed in this chapter are small. To reliably detect small associations, large samples are needed (Simmons et al., 2011). Most studies discussed in this chapter indeed rely upon relatively large samples. But not that many studies consider whether sample is capable of reliably detecting a specific effect (for a more detailed discussion of the role of power in the study of personality, see Giner-Sorolla et al., 2019). For studies relying upon correlations between trait $\mathrm{x}$ and political construct $\mathrm{y}$, the sample sizes might not need to be that large (Schönbrodt \& Perugini, 2013). However, the required sample size goes up quickly if more complex models, such as moderation effects, are specified (Giner-Sorolla et al., 2019). Going forward, more a priori power analyses should be conducted and/or posthoc sensitivity analyses reported, see for instance (Perugini, Gallucci, \& Costantini, 2018).

Recently, some studies in the personality-politics literature were preregistered (for instance, Bakker, Lelkes, \& Malka, 2021; Bromme et al., 2022; Xu et al., 2021) also when they relied upon publicly available datasets Bakker, Lelkes, and Malka (2021).

4. Transparency in the communication of results. It is not uncommon for personality and politics studies to be covered in articles with titles like: "Conservatives are from Mars, Liberals from Venus" (The Atlantic, 2012) "Your personality predicts your attitudes towards Brexit" (New Scientist 2018) or "Secrets of the right-wing brain: New study proves it - conservatives see a different, hostile world" (Salon.com, 2014). These titles, and the substance in these articles, often include strong causal claims. Moreover, the headlines and coverage suggest that personality is the important factor explaining the specific political phenomena. Yet, many studies in the personality-politics literature cannot address the nature of the causal ordering of the variables, and the effects in this literature are generally small. Journalists and university press offices are partly responsible for the misrepresentation of the research. At the same time, researchers bear the ultimate responsibility for a fair and balanced reporting of their findings.

To conclude, this chapter showed the personality-politics has contributed to our understanding of ideology, voting behavior, and political participation. At the same time, this literature will benefit from adopting open science practices, such as sharing data and materials, replication, and preregistration. Doing so will increase the replicability (Asendorpf et al., 2013), transparency (Vermeulen \& Hartmann, 2015) and ultimately also the credibility (Anvari \& Lakens, 2018) of this literature and political psychology as a field. The next volume of this handbook will, hopefully, show the progress this literature, and the field at large, has made.

\section{References}

Aarøe, L., Petersen, M. B., \& Arceneaux, K. (2017). The behavioral immune system shapes political intuitions: Why and how individual differences in disgust sensitivity underlie opposition to immigration. American Political Science Review, $111(2), 277-294$. 
Aarøe, L., Petersen, M. B., \& Arceneaux, K. (2020). The behavioral immune system shapes partisan preferences in modern democracies: Disgust sensitivity predicts voting for socially conservative parties. Political Psychology, 41(6), 1073-1091.

Abe, J. A. A. (2018). Personality and political preferences: The 2016 us presidential election. Journal of Research in Personality, 77, 70-82.

Ackermann, K., \& Ackermann, M. (2015). The big five in context: Personality, diversity and attitudes toward equal opportunities for immigrants in switzerland. Swiss Political Science Review, 21(3), 396-418.

Ackermann, K., Ackermann, M., \& Freitag, M. (2018). Opting for an open society? personality traits and attitudes toward the openness of switzerland. Comparative European Politics, 16 (3), 413-433.

Ackermann, K., Zampieri, E., \& Freitag, M. (2018). Personality and voting for a right-wing populist party-evidence from switzerland. Swiss political science review, $24(4), 545-564$.

Adorno, T., Frenkel-Brenswik, E., Levinson, D. J., \& Sanford, R. N. (1950). The authoritarian personality. Verso Books.

Ahler, D. J., \& Sood, G. (2018). The parties in our heads: Misperceptions about party composition and their consequences. The Journal of Politics, 80(3), 964-981.

Aichholzer, J., Danner, D., \& Rammstedt, B. (2018). Facets of personality and "ideological asymmetries". Journal of Research in Personality, 77, 90-100.

Aichholzer, J., \& Rammstedt, B. (2020). Can specific personality traits better explain eu attitudes? Acta Politica, 1-18.

Aichholzer, J., \& Zandonella, M. (2016). Psychological bases of support for radical right parties. Personality and Individual Differences, 96, 185-190.

Aidt, T., \& Rauh, C. (2018). The big five personality traits and partisanship in england. Electoral Studies, 54, 1-21.

Akkerman, A., Mudde, C., \& Zaslove, A. (2014). How populist are the people? measuring populist attitudes in voters. Comparative political studies, $47(9)$, $1324-1353$.

Allport, G. W. (1937). Personality: A psychological interpretation.

Allport, G. W., \& Odbert, H. S. (1936). Trait-names: A psycho-lexical study. Psychological monographs, $47(1)$, i.

Anvari, F., \& Lakens, D. (2018). The replicability crisis and public trust in psychological science. Comprehensive Results in Social Psychology, 3(3), 266-286.

Arceneaux, K., Johnson, M., \& Maes, H. H. (2012). The genetic basis of political sophistication. Twin Research and Human Genetics, 15(1), 34-41.

Arceneaux, K., \& Nicholson, S. P. (2012). Who wants to have a tea party? the who, what, and why of the tea party movement. PS, Political Science 85 Politics, 45(4), 700 .

Asendorpf, J. B., Conner, M., De Fruyt, F., De Houwer, J., Denissen, J. J., Fiedler, K., ... others (2013). Recommendations for increasing replicability in psychology. European Journal of Personality, 27(2), 108-119.

Ashton, M. C., \& Lee, K. (2007). Empirical, theoretical, and practical advantages of the hexaco model of personality structure. Personality and social psychology review, $11(2), 150-166$.

Ashton, M. C., Lee, K., \& De Vries, R. E. (2014). The hexaco honesty-humility, agreeableness, and emotionality factors: A review of research and theory. Personality and Social Psychology Review, 18(2), 139-152. 
Ashton, M. C., Lee, K., de Vries, R. E., Perugini, M., Gnisci, A., \& Sergi, I. (2006). The hexaco model of personality structure and indigenous lexical personality dimensions in italian, dutch, and english. Journal of Research in Personality, $40(6), 851-875$.

Bakker, B. N. (2017). Personality traits, income, and economic ideology. Political Psychology, 38(6), 1025-1041.

Bakker, B. N. (2018). With an open mind: A review of "open versus closed: Personality, identity, and the politics of redistribution" by johnston, lavine and federico. Social Justice Research, 31 (4), 386-399.

Bakker, B. N., \& de Vreese, C. H. (2016). Personality and european union attitudes: relationships across european union attitude dimensions. European Union Politics, 17(1), 25-45.

Bakker, B. N., Hopmann, D. N., \& Persson, M. (2015). Personality traits and party identification over time. European Journal of Political Research, 54, 197-215.

Bakker, B. N., Klemmensen, R., Nørgaard, A. S., \& Schumacher, G. (2016). Stay loyal or exit the party? how openness to experience and extroversion explain vote switching. Political psychology, 37(3), 419-429.

Bakker, B. N., Kokil, J., Dörr, T., Fasching, N., \& Lelkes, Y. (2021). Questionable and open research practices: attitudes and perceptions among quantitative communication researchers. Journal of Communication, 71 (5), 715-738.

Bakker, B. N., \& Lelkes, Y. (2018). Selling ourselves short? how abbreviated measures of personality change the way we think about personality and politics. The Journal of Politics, 80(4), 1311-1325.

Bakker, B. N., Lelkes, Y., \& Malka, A. (2020). Understanding partisan cue receptivity: Tests of predictions from the bounded rationality and expressive utility perspectives. The Journal of Politics, 82(3), 1061-1077.

Bakker, B. N., Lelkes, Y., \& Malka, A. (2021). Reconsidering the link between self-reported personality traits and political preferences. American Political Science Review, 115 (4), 1482-1498.

Bakker, B. N., Rooduijn, M., \& Schumacher, G. (2016). The psychological roots of populist voting: Evidence from the united states, the netherlands and germany. European Journal of Political Research, 55(2), 302-320.

Bakker, B. N., Schumacher, G., Gothreau, C., \& Arceneaux, K. (2020). Conservatives and liberals have similar physiological responses to threats. Nature Human Behaviour, 4(6), 613-621.

Bakker, B. N., Schumacher, G., \& Homan, M. D. (2020). Yikes! are we disgusted by politicians? Politics and the Life Sciences, 39(2), 135-153.

Bakker, B. N., Schumacher, G., \& Rooduijn, M. (2021). The populist appeal: Personality and antiestablishment communication. The Journal of Politics, 83(2), 589-601.

Balzer, A., \& Jacobs, C. M. (2011). Gender and physiological effects in connecting disgust to political preferences. Social Science Quarterly, 92(5), 1297-1313.

Barbaranelli, C., Caprara, G. V., Vecchione, M., \& Fraley, C. R. (2007). Voters' personality traits in presidential elections. Personality and Individual Differences, 42(7), 1199-1208.

Baum, M. A. (2003). Soft news and political knowledge: Evidence of absence or absence of evidence? Political communication, 20(2), 173-190.

Beattie, P., Chen, R., \& Bettache, K. (2021). When left is right and right is left: The 
psychological correlates of political ideology in china. Political Psychology.

Bem, D. J. (1987). Writing the empirical journal article. The compleat academic: A practical guide for the beginning social scientist, 2, 185-219.

Best, H. (2011). Does personality matter in politics? personality factors as determinants of parliamentary recruitment and policy preferences. Comparative Sociology, 10(6), 928-948.

Best, S. J., Krueger, B., Hubbard, C., \& Smith, A. (2001). An assessment of the generalizability of internet surveys. Social Science Computer Review, 19(2), 131-145.

Blais, J., \& Pruysers, S. (2017). The power of the dark side: personality, the dark triad, and political ambition. Personality and Individual Differences, 113, 167-172.

Block, J. (2010). The five-factor framing of personality and beyond: Some ruminations. Psychological Inquiry, 21(1), 2-25.

Block, J., \& Block, J. H. (2006a). Nursery school personality and political orientation two decades later. Journal of Research in Personality, 40 (5), 734-749.

Block, J., \& Block, J. H. (2006b). Venturing a 30-year longitudinal study. American Psychologist, 61(4), 315-327.

Bloeser, A. J., Canache, D., Mitchell, D.-G., Mondak, J. J., \& Poore, E. R. (2015). The temporal consistency of personality effects: Evidence from the b ritish h ousehold p anel s urvey. Political Psychology, 36(3), 331-340.

Bølstad, J., Dinas, E., \& Riera, P. (2013). Tactical voting and party preferences: A test of cognitive dissonance theory. Political behavior, 35(3), 429-452.

Boston, J., Homola, J., Sinclair, B., Torres, M., \& Tucker, P. D. (2018). The dynamic relationship between personality stability and political attitudes. Public Opinion Quarterly, 82(S1), 843-865.

Boukes, M., Boomgaarden, H. G., Moorman, M., \& De Vreese, C. H. (2014). News with an attitude: Assessing the mechanisms underlying the effects of opinionated news. Mass Communication and Society, 17(3), 354-378.

Boutyline, A., \& Willer, R. (2017). The social structure of political echo chambers: Variation in ideological homophily in online networks. Political Psychology, 38(3), $551-569$.

Bowman, N. D., \& Spence, P. R. (2020). Challenges and best practices associated with sharing research materials and research data for communication scholars. Communication Studies, 71(4), 708-716.

Brandt, M. J., IJzerman, H., Dijksterhuis, A., Farach, F. J., Geller, J., Giner-Sorolla, R., ... Van't Veer, A. (2014). The replication recipe: What makes for a convincing replication? Journal of Experimental Social Psychology, 50, 217-224.

Brandt, M. J., Reyna, C., Chambers, J. R., Crawford, J. T., \& Wetherell, G. (2014). The ideological-conflict hypothesis: Intolerance among both liberals and conservatives. Current Directions in Psychological Science, 23(1), 27-34.

Bromme, L., Rothmund, T., \& Azevedo, F. (2022). Mapping political trust and involvement in the personality space-a systematic review and analysis. Journal of Personality.

Buckels, E. E., Jones, D. N., \& Paulhus, D. L. (2013). Behavioral confirmation of everyday sadism. Psychological science, 24(11), 2201-2209.

Bullock, J. G., Green, D. P., \& Ha, S. E. (2010). Yes, but what's the mechanism?(don't expect an easy answer). Journal of Personality and Social Psychology, 98(4), $550-558$. 
Burisch, M. (1984). Approaches to personality inventory construction: a comparison of merits. American Psychologist, $39(3), 214$.

Camerer, C. F., Dreber, A., Holzmeister, F., Ho, T.-H., Huber, J., Johannesson, M., ... others (2018). Evaluating the replicability of social science experiments in nature and science between 2010 and 2015. Nature Human Behaviour, 2(9), 637-644.

Campbell, A., Converse, P. E., Miller, W. E., \& Donald, E. (1960). Stokes. the american voter. Ann Arbor, MI: University of Michigan Press.

Canovan, M. (1981). Populism. Houghton Mifflin Harcourt P.

Capara, G. V., Barbaranelli, C., \& Zimbardo, P. G. (1999). Personality profiles and political parties. Political psychology, 20(1), 175-197.

Caprara, G. V., Barbaranelli, C., Consiglio, C., Picconi, L., \& Zimbardo, P. G. (2003). Personalities of politicians and voters: Unique and synergistic relationships. Journal of Personality and Social Psychology, 84(4), 849.

Caprara, G. V., Schwartz, S., Capanna, C., Vecchione, M., \& Barbaranelli, C. (2006). Personality and politics: Values, traits, and political choice. Political psychology, 27(1), 1-28.

Caprara, G. V., \& Zimbardo, P. G. (2004). Personalizing politics: a congruency model of political preference. American Psychologist, 59(7), 581.

Carney, D. R., Jost, J. T., Gosling, S. D., \& Potter, J. (2008). The secret lives of liberals and conservatives: Personality profiles, interaction styles, and the things they leave behind. Political Psychology, 29(6), 807-840.

Castanho Silva, B., Jungkunz, S., Helbling, M., \& Littvay, L. (2020). An empirical comparison of seven populist attitudes scales. Political Research Quarterly, 73(2), 409-424.

Caughey, D., O'Grady, T. O., \& Warshaw, C. (2019). Policy ideology in European Mass Publics, 1981-2016. American Political Science Review, 113(3), 674-693.

Chambers, C. (2019). The seven deadly sins of psychology: A manifesto for reforming the culture of scientific practice. Princeton University Press.

Cheng, A., Zamarro, G., \& Orriens, B. (2020). Personality as a predictor of unit nonresponse in an internet panel. Sociological Methods 86 Research, 49(3), $672-698$.

Chirumbolo, A., \& Leone, L. (2010). Personality and politics: The role of the hexaco model of personality in predicting ideology and voting. Personality and Individual Differences, 49(1), 43-48.

Choma, B. L., \& Hanoch, Y. (2017). Cognitive ability and authoritarianism: Understanding support for trump and clinton. Personality and Individual Differences, 106, 287-291.

Clifford, S., Jewell, R. M., \& Waggoner, P. D. (2015). Are samples drawn from mechanical turk valid for research on political ideology? Research $\&$ Politics, 2(4), 2053168015622072.

Cooper, C. A., Golden, L., \& Socha, A. (2013). The big five personality factors and mass politics. Journal of Applied Social Psychology, 43(1), 68-82.

Cooper, C. A., McCord, D. M., \& Socha, A. (2010). Evaluating the college sophomore problem: The case of personality and politics. The Journal of psychology, 145(1), 23-37.

Costa, P. T., \& McCrae, R. R. (1988). Personality in adulthood: a six-year longitudinal study of self-reports and spouse ratings on the neo personality inventory. Journal of Personality and Social Psychology, 54 (5), 853. 
Costa, P. T., \& McCrae, R. R. (1995). Domains and facets: Hierarchical personality assessment using the Revised NEO Personality Inventory. Journal of Personality Assessment, 64(1), 21-50.

Costa Jr, P. T., \& McCrae, R. R. (1992). Four ways five factors are basic. Personality and Individual Differences, 13(6), 653-665.

Costa Jr, P. T., \& McCrae, R. R. (2008). The revised neo personality inventory (neo-pi-r). Sage Publications, Inc.

Costa Jr, P. T., McCrae, R. R., \& Dye, D. A. (1991). Facet scales for agreeableness and conscientiousness: A revision of the neo personality inventory. Personality and individual Differences, 12(9), 887-898.

Costello, T. H., Clark, C. J., \& Tetlock, P. (2021). Shoring up the shaky psychological foundations of a micro-economic model of ideology: Adversarial collaboration solutions.

Crawford, J. T., \& Brandt, M. J. (2019). Who is prejudiced, and toward whom? the big five traits and generalized prejudice. Personality and Social Psychology Bulletin, 45(10), 1455-1467.

Credé, M., Harms, P., Niehorster, S., \& Gaye-Valentine, A. (2012). An evaluation of the consequences of using short measures of the big five personality traits. Journal of Personality and Social Psychology, 102(4), 874.

Cronbach, L. J. (1949). Essentials of psychological testing.

Curtis, K. A. (2016). Personality's effect on european identification. European union politics, 17(3), 429-456.

Curtis, K. A., \& Miller, S. V. (2021). A (supra) nationalist personality? the big five's effects on political-territorial identification. European Union Politics, 1465116520988907.

Curtis, K. A., \& Nielsen, J. H. (2018). Predispositions matter. . but how? ideology as a mediator of personality's effects on eu support in five countries. Political Psychology, 39(6), 1251-1270.

Curtis, K. A., \& Nielsen, J. H. (2020). Personality's cross-national impact across eu attitude dimensions. Research \& Politics, 7(4), 2053168020972812.

Dawes, C. T., Cesarini, D., Fowler, J. H., Johannesson, M., Magnusson, P. K., \& Oskarsson, S. (2014). The relationship between genes, psychological traits, and political participation. American Journal of Political Science, 58(4), 888-903.

Dawes, C. T., \& Weinschenk, A. C. (2020). On the genetic basis of political orientation. Current Opinion in Behavioral Sciences, 34, 173-178.

Dawkins, R. (2017). Political participation, personality, and the conditional effect of campaign mobilization. Electoral Studies, 45, 100-109.

Denissen, J. J., Geenen, R., Soto, C. J., John, O. P., \& Van Aken, M. A. (2019). The big five inventory-2: Replication of psychometric properties in a dutch adaptation and first evidence for the discriminant predictive validity of the facet scales. Journal of Personality Assessment, 13(1), 246-263.

De Vries, R. E. (2013). The 24-item brief hexaco inventory (bhi). Journal of Research in Personality, $47(6), 871-880$.

de Vries, R. E., Wesseldijk, L. W., Karinen, A. K., Jern, P., \& Tybur, J. M. (2021). Relations between hexaco personality and ideology variables are mostly genetic in nature. European Journal of Personality, 08902070211014035.

DeYoung, C. G., Quilty, L. C., \& Peterson, J. B. (2007). Between facets and domains: 10 aspects of the big five. Journal of personality and social psychology, 93(5), 880. 
Dietrich, B. J., Lasley, S., Mondak, J. J., Remmel, M. L., \& Turner, J. (2012). Personality and legislative politics: The big five trait dimensions among us state legislators. Political Psychology, 33(2), 195-210.

Digman, J. M. (1990). Personality structure: Emergence of the five-factor model. Annual Review of Psychology, 41(1), 417-440.

Dinesen, P. T., Klemmensen, R., \& Nørgaard, A. S. (2016). Attitudes toward immigration: The role of personal predispositions. Political Psychology, 37(1), $55-72$.

Donnellan, M. B., Oswald, F. L., Baird, B. M., \& Lucas, R. E. (2006). The mini-ipip scales: tiny-yet-effective measures of the big five factors of personality. Psychological assessment, 18(2), 192.

Druckman, J. N., \& Kam, C. D. (2011). Students as experimental participants. Cambridge handbook of experimental political science, 1, 41-57.

Druschel, B., \& Sherman, M. F. (1999). Disgust sensitivity as a function of the big five and gender. Personality and Individual Differences, 26(4), 739-748.

Duckitt, J., \& Sibley, C. G. (2010). Personality, ideology, prejudice, and politics: A dual-process motivational model. Journal of Personality, 78(6), 1861-1894.

Duckitt, J., \& Sibley, C. G. (2016). Personality, ideological attitudes, and group identity as predictors of political behavior in majority and minority ethnic groups. Political Psychology, 37(1), 109-124.

Dunn, K. (2015). Preference for radical right-wing populist parties among exclusive-nationalists and authoritarians. Party Politics, 21(3), 367-380.

Dynes, A. M., Hassell, H. J., \& Miles, M. R. (2019). The personality of the politically ambitious. Political Behavior, 41(2), 309-336.

Edmonds, G. W., Goldberg, L. R., Hampson, S. E., \& Barckley, M. (2013). Personality stability from childhood to midlife: Relating teachers' assessments in elementary school to observer-and self-ratings 40 years later. Journal of research in personality, 47(5), 505-513.

Ekstrom, P. D., \& Federico, C. M. (2019). Personality and political preferences over time: Evidence from a multiwave longitudinal study. Journal of personality, $87(2), 398-412$.

Elson, M., \& Przybylski, A. K. (2017). The science of technology and human behavior. Hogrefe Publishing.

Emmons, R. A. (1984). Factor analysis and construct validity of the narcissistic personality inventory $\backslash$. Journal of Personality Assessment, 48(3), 291-300.

Engelhardt, A. M., Feldman, S., \& Hetherington, M. J. (2021). Advancing the measurement of authoritarianism. Political Behavior, 1-24.

Erdheim, J., Wang, M., \& Zickar, M. J. (2006). Linking the big five personality constructs to organizational commitment. Personality and Individual Differences, 41(5), 959-970.

Erisen, C., Guidi, M., Martini, S., Toprakkiran, S., Isernia, P., \& Littvay, L. (2021). Psychological correlates of populist attitudes. Political Psychology.

Esser, F., De Vreese, C. H., Strömbäck, J., Van Aelst, P., Aalberg, T., Stanyer, J., ... others (2012). Political information opportunities in europe: A longitudinal and comparative study of thirteen television systems. The International Journal of Press/Politics, 17(3), 247-274.

Eysenck, S., \& Eysenck, H. (1968). The measurement of psychoticism: a study of factor stability and reliability. British Journal of Social and Clinical Psychology, 7(4), 
286-294.

Fasching, N., Arceneaux, K., \& Bakker, B. N. (2021). Childhood personality and adult ideology: Evidence from two conceptual replications. Working paper.

Fatke, M. (2017). Personality traits and political ideology: A first global assessment. Political Psychology, 38(5), 881-899.

Fatke, M. (2019). The personality of populists: How the big five traits relate to populist attitudes. Personality and Individual Differences, 139, 138-151.

Federico, C. M., \& Malka, A. (2018). The contingent, contextual nature of the relationship between needs for security and certainty and political preferences: Evidence and implications. Political Psychology, 39, 3-48.

Feher, A., \& Vernon, P. A. (2021). Looking beyond the big five: A selective review of alternatives to the big five model of personality. Personality and Individual Differences, 169, 110002.

Feldman, S. (2003). Enforcing social conformity: A theory of authoritarianism. Political psychology, 24(1), 41-74.

Feldman, S., Huddy, L., Wronski, J., \& Lown, P. (2020). The interplay of empathy and individualism in support for social welfare policies. Political Psychology, 41(2), 343-362.

Feldman, S., \& Johnston, C. (2014). Understanding the determinants of political ideology: Implications of structural complexity. Political Psychology, 35(3), 337-358.

Feldman, S., \& Stenner, K. (1997). Perceived threat and authoritarianism. Political Psychology, 18(4), 741-770.

Fernández-del Río, E., Ramos-Villagrasa, P. J., \& Barrada, J. R. (2020). Bad guys perform better? the incremental predictive validity of the dark tetrad over big five and honesty-humility. Personality and Individual Differences, 154, 109700.

Finn, S. (1997). Origins of media exposure: Linking personality traits to tv, radio, print, and film use. Communication research, $24(5), 507-529$.

Fiske, D. W. (1949). Consistency of the factorial structures of personality ratings from different sources. The Journal of Abnormal and Social Psychology, $44(3), 329$.

Florczak, C., Ludeke, S. G., Klemmensen, R., Nørgaard, A. S., \& Arends, C. V. (2020). Do birds of a feather flock together? the personality traits of politicians and bureaucrats in decentralized government. Personality and Individual Differences, 163, 110065.

Fortunato, D., Hibbing, M. V., \& Mondak, J. J. (2018). The trump draw: Voter personality and support for donald trump in the 2016 republican nomination campaign. American Politics Research, 46 (5), 785-810.

Fournier, P., Petersen, M. B., \& Soroka, S. (2021). The political phenotype of the disgust sensitive: Correlates of a new abbreviated measure of disgust sensitivity. Electoral Studies, 72, 102347.

Fraley, R. C., Griffin, B. N., Belsky, J., \& Roisman, G. I. (2012). Developmental antecedents of political ideology: A longitudinal investigation from birth to age 18 years. Psychological Science, $23(11), 1425-1431$.

Francescato, D., Lauriola, M., Giacomantonio, M., \& Mebane, M. E. (2020). Do personality traits and personal values predict career efficacy and career progression of successful political women? an exploratory study. Personality and Individual Differences, 160, 109918.

Franco, A., Malhotra, N., \& Simonovits, G. (2015). Underreporting in political science 
survey experiments: Comparing questionnaires to published results. Political Analysis, 23(2), 306-312.

Franco, A., Malhotra, N., \& Simonovits, G. (2016). Underreporting in psychology experiments: Evidence from a study registry. Social Psychological and Personality Science, 7(1), 8-12.

Funder, D. C., \& Ozer, D. J. (2019). Evaluating effect size in psychological research: Sense and nonsense. Advances in Methods and Practices in Psychological Science, 2(2), 156-168.

Galais, C., \& Rico, G. (2021). An unjustified bad reputation? the dark triad and support for populism. Electoral Studies, 72, 102357.

Gallego, A., \& Pardos-Prado, S. (2014). The big five personality traits and attitudes towards immigrants. Journal of Ethnic and Migration Studies, 40(1), 79-99.

Gelman, A., \& Carlin, J. (2014). Beyond power calculations: Assessing type s (sign) and type m (magnitude) errors. Perspectives on Psychological Science, 9(6), 641-651.

Gelman, A., \& Loken, E. (2014). The statistical crisis in science: data-dependent analysis-a "garden of forking paths"-explains why many statistically significant comparisons don't hold up. American Scientist, 102(6), 460-466.

Gerber, A. S., Huber, G. A., Doherty, D., \& Dowling, C. M. (2011a). The big five personality traits in the political arena. Annual Review of Political Science, 14(1), 265-287.

Gerber, A. S., Huber, G. A., Doherty, D., \& Dowling, C. M. (2011b). Personality traits and the consumption of political information. American Politics Research, 39(1), $32-84$.

Gerber, A. S., Huber, G. A., Doherty, D., \& Dowling, C. M. (2012). Personality and the strength and direction of partisan identification. Political Behavior, 34(4), 653-688.

Gerber, A. S., Huber, G. A., Doherty, D., \& Dowling, C. M. (2013). Assessing the stability of psychological and political survey measures. American Politics Research, 41(1), 54-75.

Gerber, A. S., Huber, G. A., Doherty, D., Dowling, C. M., \& Ha, S. E. (2010). Personality and political attitudes: Relationships across issue domains and political contexts. American Political Science Review, 104(1), 111-133.

Gerber, A. S., Huber, G. A., Doherty, D., Dowling, C. M., \& Panagopoulos, C. (2013). Big five personality traits and responses to persuasive appeals: Results from voter turnout experiments. Political Behavior, 35(4), 687-728.

Gertler, A. L., \& Bullock, J. G. (2017). Reference rot: An emerging threat to transparency in political science. PS, Political Science $\&$ Politics, $50(1), 166$.

Giner-Sorolla, R., Aberson, C., Bostyn, D., Carpenter, T., Conrique, B., Lewis, N., \& Soderberg, C. (2019). Power to detect what? considerations for planning and evaluating sample size. Department of Psychology, East Carolina University.

Goldberg, L. R. (1990). An alternative" description of personality": the big-five factor structure. Journal of personality and social psychology, 59(6), 1216.

Goldberg, L. R. (1992). The development of markers for the big-five factor structure. Psychological assessment, 4(1), 26.

Goldberg, L. R., et al. (1999). A broad-bandwidth, public domain, personality inventory measuring the lower-level facets of several five-factor models. Personality psychology in Europe, 7(1), 7-28.

Gosling, S. D., Rentfrow, P. J., \& Swann Jr, W. B. (2003). A very brief measure of the 
big-five personality domains. Journal of Research in Personality, 37(6), 504-528.

Gravelle, T. B., Reifler, J., \& Scotto, T. J. (2020). Personality traits and foreign policy attitudes: a cross-national exploratory study. Personality and Individual Differences, 153, 109607.

Ha, S. E. (2019). Personality correlates of political support: Evidence from south korea. Asian Journal for Public Opinion Research, 7(4), 207-225.

Ha, S. E., Kim, S., \& Jo, S. H. (2013). Personality traits and political participation: Evidence from s outh k orea. Political Psychology, 34(4), 511-532.

Hall, M. E., Hollibaugh, G. E., Klingler, J. D., \& Ramey, A. J. (2021). Attributes beyond attitudes: Personality traits on the us supreme court. the Journal of Politics.

Hanania, R. (2017). The personalities of politicians: A big five survey of american legislators. Personality and Individual Differences, 108, 164-167.

Harteveld, E., Kokkonen, A., \& Dahlberg, S. (2017). Adapting to party lines: the effect of party affiliation on attitudes to immigration. West European Politics, 40(6), $1177-1197$.

Hatemi, P. K., \& Fazekas, Z. (2018). Narcissism and political orientations. American Journal of Political Science, 62(4), 873-888.

Hatemi, P. K., Medland, S. E., Klemmensen, R., Oskarsson, S., Littvay, L., Dawes, C. T., ... others (2014). Genetic influences on political ideologies: Twin analyses of 19 measures of political ideologies from five democracies and genome-wide findings from three populations. Behavior genetics, 44 (3), 282-294.

Hatemi, P. K., \& Verhulst, B. (2015). Political attitudes develop independently of personality traits. PloS one, 10(3).

Henrich, J., Heine, S. J., \& Norenzayan, A. (2010). Most people are not weird. Nature, 466(7302), 29-29.

Hibbing, J. R., Smith, K. B., \& Alford, J. R. (2013). Predisposed: Liberals, conservatives, and the biology of political differences. Routledge.

Hibbing, J. R., Smith, K. B., \& Alford, J. R. (2014). Differences in negativity bias underlie variations in political ideology. Behaviour and Brain Sciences.

Hibbing, M. V., Cawvey, M., Deol, R., Bloeser, A. J., \& Mondak, J. J. (2019). The relationship between personality and response patterns on public opinion surveys: The big five, extreme response style, and acquiescence response style. International Journal of Public Opinion Research, 31(1), 161-177.

Hirsh, J. B., DeYoung, C. G., Xu, X., \& Peterson, J. B. (2010). Compassionate liberals and polite conservatives: Associations of agreeableness with political ideology and moral values. Personality and Social Psychology Bulletin, 36(5), 655-664.

Hodson, G., Hogg, S. M., \& MacInnis, C. C. (2009). The role of "dark personalities"(narcissism, machiavellianism, psychopathy), big five personality factors, and ideology in explaining prejudice. Journal of Research in Personality, $43(4), 686-690$.

Huber, G. A., \& Malhotra, N. (2017). Political homophily in social relationships: Evidence from online dating behavior. The Journal of Politics, 79(1), 269-283.

Jakobwitz, S., \& Egan, V. (2006). The dark triad and normal personality traits. Personality and Individual Differences, 40(2), 331-339.

Johnston, C. D., Lavine, H. G., \& Federico, C. M. (2017). Open versus closed: Personality, identity, and the politics of redistribution. Cambridge University Press. 
Joly, J. K., Hofmans, J., \& Loewen, P. (2018). Personality and party ideology among politicians. a closer look at political elites from canada and belgium. Frontiers in Psychology, 9, 552 .

Joly, J. K., Soroka, S., \& Loewen, P. (2019). Nice guys finish last: Personality and political success. Acta Politica, 54 (4), 667-683.

Jonason, P. K. (2014). Personality and politics. Personality and Individual Differences, $71,181-184$.

Jonason, P. K., \& Webster, G. D. (2010). The dirty dozen: a concise measure of the dark triad. Psychological Assessment, 22(2), 420.

Jost, J. T., Federico, C. M., \& Napier, J. L. (2009). Political ideology: Its structure, functions, and elective affinities. Annual Review of Psychology, 60, 307-337.

Jost, J. T., Glaser, J., Kruglanski, A. W., \& Sulloway, F. J. (2003). Political conservatism as motivated social cognition. Psychological Bulletin, 129(3), 339.

Jost, J. T., Stern, C., Rule, N. O., \& Sterling, J. (2017). The politics of fear: Is there an ideological asymmetry in existential motivation? Social Cognition, 35(4), 324-353.

Kalmoe, N. P. (2014). Fueling the fire: Violent metaphors, trait aggression, and support for political violence. Political Communication, 31(4), 545-563.

Kam, C. D., \& Estes, B. A. (2016). Disgust sensitivity and public demand for protection. The Journal of Politics, 78(2), 481-496.

Kam, C. D., \& Simas, E. N. (2012). Risk attitudes, candidate characteristics, and vote choice. Public Opinion Quarterly, 76(4), 747-760.

Kandler, C., Bell, E., Shikishima, C., Yamagata, S., \& Riemann, R. (2015). The genetic foundations of attitude formation: The case of left-right political orientations. Emerging trends in the social and behavioral sciences: An interdisciplinary, searchable, and linkable resource, 1-21.

Kerr, N. L. (1998). Harking: Hypothesizing after the results are known. Personality and Social Psychology Review, 2(3), 196-217.

Klemmensen, R., Hatemi, P. K., Hobolt, S. B., Petersen, I., Skytthe, A., \& Nørgaard, A. S. (2012). The genetics of political participation, civic duty, and political efficacy across cultures: Denmark and the united states. Journal of Theoretical Politics, 24(3), 409-427.

Klemmensen, R., Hatemi, P. K., Hobolt, S. B., Skytthe, A., \& Nørgaard, A. S. (2012). Heritability in political interest and efficacy across cultures: Denmark and the united states. Twin Research and Human Genetics, 15(1), 15-20.

Klingler, J. D., Hollibaugh, G. E., \& Ramey, A. J. (2018). Don't know what you got: A bayesian hierarchical model of neuroticism and nonresponse. Political Science Research and Methods, 6(3), 549-569.

Klingler, J. D., Hollibaugh, G. E., \& Ramey, A. J. (2019). What i like about you: Legislator personality and legislator approval. Political Behavior, 41(2), 499-525.

Koppensteiner, M. (2011). Perceiving personality in simple motion cues. Journal of Research in Personality, 45 (4), 358-363.

Kraaykamp, G., \& Van Eijck, K. (2005). Personality, media preferences, and cultural participation. Personality and individual differences, 38(7), 1675-1688.

Laajaj, R., Macours, K., Hernandez, D. A. P., Arias, O., Gosling, S. D., Potter, J., ... Vakis, R. (2019). Challenges to capture the big five personality traits in non-weird populations. Science advances, 5(7), eaaw5226.

Landau-Wells, M., \& Saxe, R. (2020). Political preferences and threat perception: 
Opportunities for neuroimaging and developmental research. Current Opinion in Behavioral Sciences, 34, 58-63.

Lane, R. E. (1955). Political personality and electoral choice. The American Political Science Review, 49(1), 173-190.

Lee, K., \& Ashton, M. C. (2006). Further assessment of the hexaco personality inventory: Two new facet scales and an observer report form. Psychological Assessment, 18(2), 182.

Lee, K., \& Ashton, M. C. (2008). The hexaco personality factors in the indigenous personality lexicons of english and 11 other languages. Journal of Personality, $76(5), 1001-1054$.

Leone, L., Desimoni, M., \& Chirumbolo, A. (2012). Hexaco, social worldviews and socio-political attitudes: A mediation analysis. Personality and Individual Differences, 53(8), 995-1001.

Ludeke, S. G., Klitgaard, C. N., \& Vitriol, J. (2018). Comprehensively-measured authoritarianism does predict vote choice: The importance of authoritarianism's facets, ideological sorting, and the particular candidate. Personality and Individual Differences, 123, 209-216.

Ludeke, S. G., \& Larsen, E. G. (2017). Problems with the big five assessment in the world values survey. Personality and Individual Differences, 112, 103-105.

Ludeke, S. G., Tagar, M. R., \& DeYoung, C. G. (2016). Not as different as we want to be: Attitudinally consistent trait desirability leads to exaggerated associations between personality and sociopolitical attitudes. Political Psychology, 37(1), 125-135.

Ludeke, S. G., Weisberg, Y. J., \& DeYoung, C. G. (2013). Idiographically desirable responding: Individual differences in perceived trait desirability predict overclaiming. European Journal of Personality, 27(6), 580-592.

Luttig, M. D. (2021). Reconsidering the relationship between authoritarianism and republican support in 2016 and beyond. The Journal of Politics, 83(2), 000-000.

Lyons, J., Sokhey, A. E., McClurg, S. D., \& Seib, D. (2016). Personality, interpersonal disagreement, and electoral information. The Journal of Politics, 78(3), 806-821.

Malka, A., Lelkes, Y., \& Holzer, N. (2017). Rethinking the rigidity of the right model: Three suboptimal methodological practices and their implications. In Politics of social psychology (pp. 126-146). Psychology Press.

Malka, A., Soto, C. J., Inzlicht, M., \& Lelkes, Y. (2014). Do needs for security and certainty predict cultural and economic conservatism? a cross-national analysis. Journal of Personality and Social Psychology, 106(6), 1031.

McAdams, D. P., \& Olson, B. D. (2010). Personality development: Continuity and change over the life course. Annual review of psychology, 61, 517-542.

McCann, J. A. (1997). Electoral choices and core value change: The 1992 presidential campaign. American Journal of Political Science, 564-583.

McClosky, H. (1958). Conservatism and personality. American Political Science Review, 52(1), 27-45.

McCrae, R. R. (1996). Social consequences of experiential openness. Psychological Bulletin, 120(3), 323.

McCrae, R. R., \& Costa, P. T. (1985). Updating norman's" adequacy taxonomy": Intelligence and personality dimensions in natural language and in questionnaires. Journal of personality and social psychology, 49(3), 710.

Merton, R. K. (1942). A note on science and democracy. J. Legal \& Pol. Soc., 1, 115. 
Mischel, W., \& Shoda, Y. (1995). A cognitive-affective system theory of personality: reconceptualizing situations, dispositions, dynamics, and invariance in personality structure. Psychological review, 102(2), 246.

Mondak, J. J. (2010). Personality and the foundations of political behavior. Cambridge University Press.

Mondak, J. J., Canache, D., Seligson, M. A., \& Hibbing, M. V. (2011). The participatory personality: evidence from latin america. British Journal of Political Science, 41(1), 211-221.

Mondak, J. J., \& Halperin, K. D. (2008). A framework for the study of personality and political behaviour. British Journal of Political Science, 335-362.

Mondak, J. J., Hibbing, M. V., Canache, D., Seligson, M. A., \& Anderson, M. R. (2010). Personality and civic engagement: An integrative framework for the study of trait effects on political behavior. American political science review, 85-110.

Mudde, C. (2004). The populist zeitgeist. Government and opposition, 39(4), 541-563.

Mullainathan, S., \& Washington, E. (2009). Sticking with your vote: Cognitive dissonance and political attitudes. American Economic Journal: Applied Economics, 1(1), 86-111.

Nai, A. (2019). The electoral success of angels and demons: Big five, dark triad, and performance at the ballot box. Journal of Social and Political Psychology, 7(2), 830-862.

Nai, A., \& Maier, J. (2018). Perceived personality and campaign style of hillary clinton and donald trump. Personality and Individual Differences, 121, 80-83.

Nai, A., \& Maier, J. (2019). Can anyone be objective about donald trump? assessing the personality of political figures. Journal of Elections, Public Opinion and Parties, 1-26.

Nai, A., Maier, J., \& Vranić, J. (2021). Personality goes a long way (for some). an experimental investigation into candidate personality traits, voters' profile, and perceived likeability. Frontiers in Political Science, 3, 4.

Nai, A., \& Martinez i Coma, F. (2019). The personality of populists: provocateurs, charismatic leaders, or drunken dinner guests? West European Politics, 42(7), $1337-1367$.

Nørgaard, A. S., \& Klemmensen, R. (2019). The personalities of danish mps: Trait-and aspect-level differences. Journal of Personality, 87(2), 267-275.

Nosek, B. A., Ebersole, C. R., DeHaven, A. C., \& Mellor, D. T. (2018). The preregistration revolution. Proceedings of the National Academy of Sciences, 115(11), 2600-2606.

Nuijten, M. B., Bakker, M., Maassen, E., \& Wicherts, J. (2018). Verify original results through reanalysis before replicating: a commentary on "making replication mainstream" by rolf a. zwaan, alexander etz, richard e. lucas, \& m. brent donnellan.

Osborne, D., \& Sibley, C. G. (2012). Does personality matter? openness correlates with vote choice, but particularly for politically sophisticated voters. Journal of research in Personality, 46(6), 743-751.

Osborne, D., \& Sibley, C. G. (2020). Does openness to experience predict changes in conservatism? a nine-wave longitudinal investigation into the personality roots to ideology. Journal of Research in Personality, 103979.

Osborne, D., Wootton, L. W., \& Sibley, C. G. (2013). Are liberals agreeable or not? Social Psychology. 
Patterson, T. E. (2000). Doing well and doing good. Available at SSRN 257395.

Paulhus, D. L., \& Williams, K. M. (2002). The dark triad of personality: Narcissism, machiavellianism, and psychopathy. Journal of Research in Personality, 36(6), 556-563.

Paunonen, S. V., \& Ashton, M. C. (2001, March). Big five predictors of academic achievement. Journal of Research in Personality, 35(1), 78-90.

Perugini, M., Gallucci, M., \& Costantini, G. (2018). A practical primer to power analysis for simple experimental designs. International Review of Social Psychology, 31(1).

Pruysers, S. (2020). A psychological predisposition towards populism? evidence from canada. Contemporary Politics, 1-20.

Ramey, A. J., Klingler, J. D., \& Hollibaugh, G. E. (2019). Measuring elite personality using speech. Political Science Research and Methods, 7(1), 163-184.

Ramey, A. J., Klingler, J. D., \& Hollibaugh Jr, G. E. (2017). More than a feeling: Personality, polarization, and the transformation of the us congress. University of Chicago Press.

Rammstedt, B., \& John, O. P. (2007). Measuring personality in one minute or less: A 10-item short version of the big five inventory in english and german. Journal of research in Personality, 41(1), 203-212.

Reinemann, C., Stanyer, J., Scherr, S., \& Legnante, G. (2012). Hard and soft news: A review of concepts, operationalizations and key findings. Journalism, 13(2), 221-239.

Rentfrow, P. J., Goldberg, L. R., \& Zilca, R. (2011). Listening, watching, and reading: The structure and correlates of entertainment preferences. Journal of personality, $79(2), 223-258$.

Rentfrow, P. J., Jost, J. T., Gosling, S. D., \& Potter, J. (2009). Statewide differences in personality predict voting patterns in 1996-2004 us presidential elections. Social and psychological bases of ideology and system justification, 1, 314-349.

Rice, M. G., Remmel, M. L., \& Mondak, J. J. (2021). Personality on the hill: Expert evaluations of us senators' psychological traits. Political Research Quarterly, $74(3), 674-687$.

Riemann, R., Grubich, C., Hempel, S., Mergl, S., \& Richter, M. (1993). Personality and attitudes towards current political topics. Personality and individual differences, $15(3), 313-321$.

Roberts, B. W., \& DelVecchio, W. F. (2000). The rank-order consistency of personality traits from childhood to old age: a quantitative review of longitudinal studies. Psychological bulletin, 126(1), 3-25.

Rooduijn, M., Van Der Brug, W., \& De Lange, S. L. (2016). Expressing or fuelling discontent? the relationship between populist voting and political discontent. Electoral Studies, 43, 32-40.

Rothschild, J. E., Howat, A. J., Shafranek, R. M., \& Busby, E. C. (2019). Pigeonholing partisans: Stereotypes of party supporters and partisan polarization. Political Behavior, 41(2), 423-443.

Rubenzer, S. J., Faschingbauer, T. R., \& Ones, D. S. (2000). Assessing the us presidents using the revised neo personality inventory. Assessment, 7(4), 403-419.

Rudolph, T. J., \& Popp, E. (2007). An information processing theory of ambivalence. Political Psychology, 28(5), 563-585.

Sagiv, L., Roccas, S., \& Hazan, O. (2012). Identification with groups: The role of 
personality and context. Journal of Personality, 80(2), 345-374.

Schmitt, D. P., Allik, J., McCrae, R. R., \& Benet-Martínez, V. (2007). The geographic distribution of big five personality traits: Patterns and profiles of human self-description across 56 nations. Journal of cross-cultural psychology, 38(2), $173-212$.

Schoen, H. (2007). Personality traits and foreign policy attitudes in german public opinion. Journal of Conflict Resolution, 51 (3), 408-430.

Schoen, H., \& Schumann, S. (2007). Personality traits, partisan attitudes, and voting behavior. evidence from germany. Political Psychology, 28(4), 471-498.

Schönbrodt, F. D., \& Perugini, M. (2013). At what sample size do correlations stabilize? Journal of Research in Personality, 47(5), 609-612.

Schoonvelde, M., Schumacher, G., \& Bakker, B. N. (2019). Friends with text as data benefits: Assessing and extending the use of automated text analysis in political science and political psychology. Journal of Social and Political Psychology, 7(1), 124-143.

Schumacher, G., \& Zettler, I. (2019). House of cards or west wing? self-reported hexaco traits of danish politicians. Personality and Individual Differences, 141, 173-181.

Schwartz, S. H. (1992). Universals in the content and structure of values: Theoretical advances and empirical tests in 20 countries. In Advances in experimental social psychology (Vol. 25, pp. 1-65). Elsevier.

Scott, C., \& Medeiros, M. (2020). Personality and political careers: What personality types are likely to run for office and get elected? Personality and individual differences, 152, 109600.

Sears, D. O. (1986). College sophomores in the laboratory: Influences of a narrow data base on social psychology's view of human nature. Journal of personality and social psychology, 51(3), 515.

Sherlock, J. M., Zietsch, B. P., Tybur, J. M., \& Jern, P. (2016). The quantitative genetics of disgust sensitivity. Emotion, 16(1), 43.

Shim, J. W., \& Paul, B. (2007). Effects of personality types on the use of television genre. Journal of Broadcasting \& Electronic Media, 51 (2), 287-304.

Sibley, C. G., Osborne, D., \& Duckitt, J. (2012). Personality and political orientation: Meta-analysis and test of a threat-constraint model. Journal of Research in Personality, 46(6), 664-677.

Simmons, J. P., Nelson, L. D., \& Simonsohn, U. (2011). False-positive psychology: Undisclosed flexibility in data collection and analysis allows presenting anything as significant. Psychological Science, 22(11), 1359-1366.

Skarlicki, D. P., Folger, R., \& Tesluk, P. (1999). Personality as a moderator in the relationship between fairness and retaliation. Academy of management journal, 42(1), 100-108.

Smith, K. B., Oxley, D., Hibbing, M. V., Alford, J. R., \& Hibbing, J. R. (2011). Disgust sensitivity and the neurophysiology of left-right political orientations. PloS one, 6(10), e25552.

Soto, C. J. (2019). How replicable are links between personality traits and consequential life outcomes? the life outcomes of personality replication project. Psychological Science, 30(5), 711-727.

Soto, C. J., \& John, O. P. (2017). The next big five inventory (bfi-2): Developing and assessing a hierarchical model with 15 facets to enhance bandwidth, fidelity, and predictive power. Journal of personality and social psychology, 113(1), 117. 
Stenner, K. (2005). The authoritarian dynamic. Cambridge university press.

Talay, L., \& De Coninck, D. (2020). Exploring the link between personality traits and european attitudes towards refugees. International Journal of Intercultural Relations, 77, 13-24.

Tillman, E. R. (2013). Authoritarianism and citizen attitudes towards european integration. European Union Politics, 14(4), 566-589.

Treier, S., \& Hillygus, D. S. (2009). The nature of political ideology in the contemporary electorate. Public Opinion Quarterly, 73(4), 679-703.

Trilling, D., \& Schoenbach, K. (2013). Skipping current affairs: The non-users of online and offline news. European Journal of Communication, 28(1), 35-51.

Tupes, E. C., \& Christal, R. E. (1992). Recurrent personality factors based on trait ratings. Journal of Personality, 60(2), 225-251.

Tybur, J. M., Lieberman, D., \& Griskevicius, V. (2009). Microbes, mating, and morality: individual differences in three functional domains of disgust. Journal of Personality and Social Psychology, 97(1), 103.

Valentino, N. A., Zhirkov, K., Hillygus, D. S., \& Guay, B. (2020). The consequences of personality biases in online panels for measuring public opinion. Public Opinion Quarterly, 84 (2), 446-468.

Valkenburg, P. M., \& Peter, J. (2013). The differential susceptibility to media effects model. Journal of Communication, 63(2), 221-243.

Van Hiel, A., \& Mervielde, I. (2004). Openness to experience and boundaries in the mind: Relationships with cultural and economic conservative beliefs. Journal of Personality, $72(4), 659-686$.

Vasilopoulos, P., \& Jost, J. T. (2020). Psychological similarities and dissimilarities between left-wing and right-wing populists: Evidence from a nationally representative survey in france. Journal of research in personality, 88, 104004.

Vecchione, M., Schoen, H., Castro, J. L. G., Cieciuch, J., Pavlopoulos, V., \& Caprara, G. V. (2011). Personality correlates of party preference: The big five in five big european countries. Personality and Individual Differences, 51(6), 737-742.

Verhulst, B., Eaves, L. J., \& Hatemi, P. K. (2012). Correlation not causation: The relationship between personality traits and political ideologies. American journal of political science, 56(1), 34-51.

Vermeulen, I., \& Hartmann, T. (2015). Questionable research and publication practices in communication science (Vol. 9) (No. 4). Taylor \& Francis.

Visser, B. A., Book, A. S., \& Volk, A. A. (2017). Is hillary dishonest and donald narcissistic? a hexaco analysis of the presidential candidates' public personas. Personality and Individual Differences, 106, 281-286.

Vitriol, J. A., Larsen, E. G., Ludeke, S. G., \& Kandler, C. (2019). The generalizability of personality effects in politics. European Journal of Personality, 33(6), 631-641.

Vukasović, T., \& Bratko, D. (2015). Heritability of personality: A meta-analysis of behavior genetic studies. Psychological bulletin, 141(4), 769--785.

Wang, C.-H. (2016). Personality traits, political attitudes and vote choice: Evidence from the united states. Electoral Studies, 44, 26-34.

Weaver III, J. B. (1991). Exploring the links between personality and media preferences. Personality and individual differences, 12(12), 1293-1299.

Webster, D. M., \& Kruglanski, A. W. (1994). Individual differences in need for cognitive closure. Journal of personality and social psychology, 67(6), 1049.

Wegemer, C. M., \& Vandell, D. L. (2020). Parenting, temperament, and attachment 
security as antecedents of political orientation: Longitudinal evidence from early childhood to age 26. Developmental Psychology, 56 (7), 1360-1371.

Weinschenk, A. C., \& Dawes, C. T. (2017). The relationship between genes, personality traits, and political interest. Political Research Quarterly, 70 (3), 467-479.

Weinschenk, A. C., Dawes, C. T., Kandler, C., Bell, E., \& Riemann, R. (2019). New evidence on the link between genes, psychological traits, and political engagement. Politics and the Life Sciences, 38(1), 1-13.

Wright, J. D., \& Tomlinson, M. F. (2018). Personality profiles of hillary clinton and donald trump: Fooled by your own politics. Personality and Individual Differences, 128, 21-24.

Wuttke, A., Schimpf, C., \& Schoen, H. (2020). When the whole is greater than the sum of its parts: On the conceptualization and measurement of populist attitudes and other multidimensional constructs. American Political Science Review, 114(2), $356-374$.

Xu, X., \& Peterson, J. B. (2017). Differences in media preference mediate the link between personality and political orientation. Political Psychology, 38(1), 55-72.

Xu, X., Soto, C. J., \& Plaks, J. E. (2021). Beyond openness to experience and conscientiousness: Testing links between lower-level personality traits and american political orientation. Journal of Personality, 89, pages=754-773, publisher $=$ Wiley Online Library.

Zeigler-Hill, V., Martinez, J. L., Vrabel, J. K., Ezenwa, M. O., Oraetue, H., Nweze, T., ... Kenny, B. (2020). The darker angels of our nature: Do social worldviews mediate the associations that dark personality features have with ideological attitudes? Personality and Individual Differences, 160, 109920.

Ziller, C., \& Berning, C. C. (2021). Personality traits and public support of minority rights. Journal of Ethnic and Migration Studies, 47(3), 723-740.

Zmigrod, L., Eisenberg, I. W., Bissett, P. G., Robbins, T. W., \& Poldrack, R. A. (2021). The cognitive and perceptual correlates of ideological attitudes: a data-driven approach. Philosophical Transactions of the Royal Society B, $376(1822), 20200424$. 